\title{
WILEY-VCH
}

DOI: $10.1002 /$ ((please add manuscript number))

Article type: Full Paper

\section{Manipulation of $\mathrm{Bi}^{3+} / \mathrm{In}^{3+}$ transmutation and $\mathrm{Mn}^{2+}$-doping effect on the structure and optical properties of double perovskite $\mathrm{Cs}_{2} \mathrm{NaBi}_{1-x} \mathrm{In}_{x} \mathrm{Cl}_{6}$}

Jun Zhou", Ximing Rong", Peng Zhang, Maxim S. Molokeev, Peijia Wei, Quanlin Liu, Xiuwen Zhang ${ }^{*}$, Zhiguo Xia ${ }^{*}$

J. Zhou, P. J. Wei, Prof. Q. L. Liu, Prof. Z. G. Xia

The Beijing Municipal Key Laboratory of New Energy Materials and Technologies,

School of Materials Sciences and Engineering, University of Science and Technology Beijing,

Beijing 100083, P. R. China

E-mail: xiazg@ustb.edu.cn

Dr. X. M. Rong, Dr. P. Zhang, Prof. X. W. Zhang

Shenzhen Key Laboratory of Flexible Memory Materials and Devices,

College of Electronic Science and Technology, Shenzhen University,

Shenzhen 518060, P. R. China

E-mail: xiuwenzhang@szu.edu.cn

\section{M. Rong}

Key Laboratory of Optoelectronic Devices and Systems of Ministry of Education and Guangdong Province,

College of Optoelectronic Engineering, Shenzhen University,

Shenzhen 518060, P. R. China

Prof. M. S. Molokeev

Laboratory of Crystal Physics, Kirensky Institute of Physics,

Federal Research Center KSC SB RAS,

Krasnoyarsk 660036, Russia

Prof. M. S. Molokeev

Siberian Federal University,

Krasnoyarsk, 660041, Russia

Prof. M. S. Molokeev

Department of Physics,

Far Eastern State Transport University,

Khabarovsk, 680021 Russia

\# The two authors contribute equally to this work.

Keywords: Halide double perovskite; Bang gap energineering; $\mathrm{Mn}^{2+}$ doping 


\section{WILEY-VCH}

\section{Abstract:}

The halide double perovskite family represented by $\mathrm{A}_{2}\left(\mathrm{~B}^{+}, \dot{\mathrm{B}}^{3+}\right) \mathrm{X}_{6}$, can overcome the lead toxicity and enable the generally large band gap engineering via $\mathrm{B} / \dot{\mathrm{B}}$ sites' transmutation or exotic dopant to fulfill the emerging applications in the optoelectronic fields. Herein, we report on the design and experimental synthesis of a new family of $\mathrm{Mn}^{2+}$ doped $\mathrm{Cs}_{2} \mathrm{NaBi}_{1-x} \mathrm{In}_{x} \mathrm{Cl}_{6}$ crystals with an intense orange-yellow emission band, and the phase formation stability has been discussed via a combined experimental-theoretical approach. Depending on the manipulation of $\mathrm{Bi}^{3+} / \mathrm{In}^{3+}$ combination, the band gap increased with $\mathrm{In}^{3+}$ content, and a subsequent evolution from indirect to direct band gap was verified. First-principles calculations and parity analyses indicate a parity forbidden effect on $\mathrm{Cs}_{2} \mathrm{NaInCl}_{6}$, and a combination effect of absorption on $\mathrm{Cs}_{2} \mathrm{NaBi}_{1-x} \mathrm{In}_{x} \mathrm{Cl}_{6}$ from both $\mathrm{Cs}_{2} \mathrm{NaBiCl}_{6}$ and $\mathrm{Cs}_{2} \mathrm{NaInCl}_{6}$. The associated $\mathrm{Mn}^{2+}$-doped photoluminescence depending on the $\mathrm{Bi}^{3+} / \mathrm{In}^{3+}$ substitution has been also addressed from the variation of the different $\mathrm{Mn}-\mathrm{Cl}$ environment and neighboring-cation effect. 


\section{WILEY-VCH}

\section{Introduction}

Halide perovskites materials with a chemical formula of $\mathrm{APbX}_{3}$, where $\mathrm{A}=\mathrm{Cs}$, methylammonium; $\mathrm{X}=\mathrm{Cl}, \mathrm{Br}$, I, have recently attracted a tremendous amount of interests owing to their excellent optoelectronic properties including long carrier diffusion lengths, large absorption coefficients, and remarkable photovoltaic and light-emitting performance. ${ }^{[1]}$ Although much progress has been made, the toxicity of lead is detrimental to the environment and human body. ${ }^{[2]}$ Accordingly, the search for lead-free alternatives is attracting a lot of attentions. Recently, one of the most popular methods is the substitution of two divalent $\mathrm{Pb}^{2+}$ by a monovalent cation and a trivalent cation to form a double perovskite structure with a basic formula $\left(\mathrm{A}_{2}\left(\mathrm{~B}^{+}, \dot{\mathrm{B}}^{3+}\right) \mathrm{X}_{6}\right)\left(\mathrm{A}=\mathrm{Cs}^{+} ; \mathrm{B}=\mathrm{Na}^{+}, \mathrm{Cu}^{+}\right.$or $\mathrm{Ag}^{+} ; \dot{\mathrm{B}}=\mathrm{Bi}^{3+}, \mathrm{Sb}^{3+}$ or $\mathrm{In}^{3+} ; \mathrm{X}=\mathrm{Cl}^{-}$, $\mathrm{Br}^{-}$, or $\left.\mathrm{I}^{-}\right){ }^{[3]}$ This kind of material originated in 1970 , when it was widely used in the field of ferroelectric materials, and is best known as $\mathrm{Cs}_{2} \mathrm{NaBiCl}_{6} \cdot{ }^{[4]}$ Recently, in the light of the intense interest in halide perovskites, versatile new lead-free halide double perovskites have been synthesized, some of which can grow into crystals and have been used as sensitive and fast UV photodetectors, and solar cell absorbers, such as $\mathrm{Cs}_{2} \mathrm{AgInCl}_{6}$ and $\mathrm{Cs}_{2} \mathrm{AgBiBr}_{6}{ }^{[5]}$ However, current double perovskites generally offer large, direct or indirect forbidden band gaps, which are not a suitable solution for targeting outstanding photovoltaic performance. ${ }^{[6]}$ Chemical substitution is an effective approach for semiconductor band gap engineering, with all lattice sites of the double perovskite $\left(\mathrm{A}_{2} \mathrm{~B}^{\prime} \mathrm{B}^{\prime \prime} \mathrm{X}_{6}\right)$ available for substitution. ${ }^{[7]}$ Amongst them, B" provides the most degrees of freedom, with over 34 choices of trivalent metals available for selection. ${ }^{[8]}$ Here, using $\mathrm{Cs}_{2} \mathrm{NaBiCl}_{6}$ with an indirect band gap as a host material, we demonstrate band gap engineering through alloying of $\mathrm{In}^{3+} / \mathrm{Bi}^{3+}$ in $\mathrm{Cs}_{2} \mathrm{NaBi}_{1-x} \mathrm{In}_{x} \mathrm{Cl}_{6}$ crystals.

Manganese $\left(\mathrm{Mn}^{2+}\right)$ substitution has been normally investigated to bestow an intense dopant-sensitized orange emission, arising from the ${ }^{4} \mathrm{~T}_{1^{-}}{ }^{6} \mathrm{~A}_{1}$ transition of octahedral $\mathrm{Mn}^{2+}$, which is largely insensitive to the physical and electronic structure of the host. ${ }^{[9]}$ Very 


\section{WILEY-VCH}

recently, efforts have been devoted to synthesize $\mathrm{Mn}^{2+}$-doped $\mathrm{CsPb}(\mathrm{Cl}, \mathrm{Br})_{3}$ perovskite materials exhibiting dual emissions owing to the energy transfer process from the host semiconductor to dopant $\mathrm{Mn}^{2+}$ ions. ${ }^{[10]}$ By introducing $\mathrm{Mn}^{2+}$, this group of perovskites show some new properties, which makes them potential applications not only in optical devices but also in actuators, sensors, piezoelectrics, etc. ${ }^{[11]}$ However, except for the recent report on the luminescence of $\mathrm{Mn}^{2+}$ in $\mathrm{Cs}_{2} \mathrm{AgInCl}_{6},{ }^{[12]}$ there is no other progress on the $\mathrm{Mn}^{2+}$-doping lead-free halide double perovskite materials. Herein, we report, for the first time to the best of our knowledge, the hydrothermal crystal growth of $\mathrm{Mn}^{2+}$-doped $\mathrm{Cs}_{2} \mathrm{NaBi}_{1-x} \mathrm{In}_{x} \mathrm{Cl}_{6}$ crystals with indirect-direct band gaps character. We performed first-principles calculations to investigate the electronic and optical properties of $\mathrm{Cs}_{2} \mathrm{NaBi}_{1-\mathrm{x}} \mathrm{In}_{\mathrm{x}} \mathrm{Cl}_{6}$ and $\mathrm{Mn}^{2+}$-doping effect on the intense orange-red luminescence in this solid solution. The successful adjustment of the band gap from the $\mathrm{Mn}^{2+}$-doped $\mathrm{Cs}_{2} \mathrm{NaBi}_{1-x} \mathrm{In}_{x} \mathrm{Cl}_{6}$ crystals will expand the utility of lead-free halide double perovskites in their future.

\section{Results and discussion}

XRD patterns of the as-prepared $\mathrm{Cs}_{2} \mathrm{NaBi}_{1-x} \mathrm{In}_{x} \mathrm{Cl}_{6}(x=0,0.1,0.2,0.3,0.4,0.7,0.9$ and 1.0) samples are shown in Figure 1a. It is found that almost all peaks were successfully indexed by cubic cell $(F m-3 m)$ with parameters close to $\mathrm{Cs}_{2} \mathrm{NaBiCl}_{6}$ (elpasolite-type structure). ${ }^{[13]}$ In the meantime, we find that the characteristic diffraction peak (2 20 ) shifts to higher diffraction angles from $23.19^{\circ}$ to $23.90^{\circ}$ with increasing $\operatorname{~In}^{3+}$ content owing to the different ionic radii between $\mathrm{Bi}^{3+}$ and $\mathrm{In}^{3+}$ (Figure $1 \mathrm{~b}$ ), further suggesting that the continuous solid solution of $\mathrm{Cs}_{2} \mathrm{NaBi}_{1-x} \mathrm{In}_{x} \mathrm{Cl}_{6}$ have formed in the crystal structure. To further analyze the crystal structure of as-prepared samples, the Rietveld analysis of this series of $\mathrm{Cs}_{2} \mathrm{NaBi}_{1-x} \mathrm{In}_{x} \mathrm{Cl}_{6}$ samples has been conducted using TOPAS 4.2, in which $\mathrm{Cs}_{2} \mathrm{NaBiCl}_{6}$ was taken as starting model. Site of $\mathrm{Bi}^{3+}$ ion was occupied by $\mathrm{Bi}^{3+} / \mathrm{In}^{3+}$ ions with and the occupations were refined in assumption $\operatorname{occ}(\mathrm{Bi})+\operatorname{occ}(\mathrm{In})=1$. Based on the Rietveld refinement results, all of these samples exhibit 


\section{WILEY-VCH}

the same cubic cell $(F m-3 m)$ besides negligible peaks belonging to $\mathrm{NaCl}$ impurity, as shown in Figure $\mathrm{S} 1$. The refinement results of $\mathrm{Cs}_{2} \mathrm{NaBi}_{1-x} \mathrm{In}_{x} \mathrm{Cl}_{6}$ were stable, and the main processing and refinement parameters, including fractional atomic coordinates, isotropic displacement parameters and main bond lengths were given in Table S1, S2 and S3.

Experimentally, we found that the solid solution with the intermediate compositions can hardly obtain the pure phase compared to the two end member, $\mathrm{Cs}_{2} \mathrm{NaBiCl}_{6}$ and $\mathrm{Cs}_{2} \mathrm{NaInCl}_{6}$. For example, we cannot get the phase of $\mathrm{Cs}_{2} \mathrm{NaBi}_{1-x} \mathrm{In}_{x} \mathrm{Cl}_{6}(x=0.5)$. To investigate the structural evolution of $\mathrm{Cs}_{2} \mathrm{NaBi}_{1-x} \mathrm{In}_{x} \mathrm{Cl}_{6}$ in theory, we set an orthogonal unit cell structure with periodic supercell based from $\mathrm{Cs}_{8} \mathrm{Na}_{4} \mathrm{Bi}_{4} \mathrm{Cl}_{24}$, as shown in Figure 1c, where four $\mathrm{Bi}^{3+}$ cations $\left(B i_{A}\right.$ to $\left.B i_{D}\right)$ were gradually substituted by $\operatorname{In}^{3+}$ as $x$ in $\mathrm{Cs}_{2} \mathrm{NaBi}_{1-x} \mathrm{In}_{x} \mathrm{Cl}_{6}$ increased from 0 to 1 . After fully relaxation, three $\mathrm{Cs}_{2} \mathrm{NaBi}_{1-x} \mathrm{In}_{x} \mathrm{Cl}_{6}$ structures $(x=0.25,0.5$ and 0.75 , respectively) with the lowest total energy were chosen for further characterization. The lattice constants $\left(L_{c}\right)$ for $\mathrm{Cs}_{2} \mathrm{NaBiCl}_{6}$ and $\mathrm{Cs}_{2} \mathrm{NaInCl}_{6}$ are 11.05 and $10.74 \AA$, respectively, which are both close to our experimental measurements of 10.84 and $10.53 \AA$. For $\mathrm{Cs}_{2} \mathrm{NaBi}_{1-x} \mathrm{In}_{x} \mathrm{Cl}_{6}, L_{c}$ decreases monotonously due to the increasing of $x$. The unit cell volumes $(V)$ for $\mathrm{Cs}_{2} \mathrm{NaBiCl}_{6}$, $\mathrm{Cs}_{2} \mathrm{NaInCl}_{6}$ and $\mathrm{Cs}_{2} \mathrm{NaBi}_{1-x} \mathrm{In}_{x} \mathrm{Cl}_{6}$ are presented in Figure 1d. The decreases of the $V$ and $L_{c}$ are mainly caused by the radii difference between $\mathrm{Bi}^{3+}$ and $\mathrm{In}^{3+}$ during the cation substitution. When a relatively larger $\mathrm{Bi}^{3+}$ cation $(1.03 \AA)$ is replaced by smaller $\operatorname{In}^{3+}(0.80 \AA)$, the lattice will be inevitably shrink. However, the internal structure will be inevitably influenced due to the radii difference between $\mathrm{Bi}^{3+}$ and $\mathrm{In}^{3+}$, causing the bond length change between $\mathrm{Bi}^{3+} / \mathrm{In}^{3+}$ and their neighborhood $\mathrm{Cl}^{-}$. Figure 1e shows the average length of overall $\mathrm{Bi} / \mathrm{In}-\mathrm{Cl}$ bond $d(\mathrm{Bi} / \mathrm{In}-\mathrm{Cl})$ as a function of $x$. The average lengths of individual $\mathrm{Bi}-\mathrm{Cl}$ bond and $\mathrm{In}-\mathrm{Cl}$ bond are presented in Table S4. According to Figure 1e, the average $d(\mathrm{Bi} / \mathrm{In}-\mathrm{Cl})$ decreases monotonously due to the increase of $x$, which is corresponding to the volume shrink and is in consistent with our experimental tendency. This decrease include both effect on $d(\mathrm{Bi}-\mathrm{Cl})$ and $d(\mathrm{In}-\mathrm{Cl})$, which performed the same tendency of linearly gradient down, as shown in Table S4. 


\section{WILEY-VCH}

The linear slopes for $V$ and $d(\mathrm{Bi} / \mathrm{In}-\mathrm{Cl})$ as function of $x$ are -108.07 and -0.17 , respectively, which are in good agreement with our experimental measurements of -105.84 and -0.16 . In order to investigate the stability of $\mathrm{Cs}_{2} \mathrm{NaBi}_{1-x} \mathrm{In}_{x} \mathrm{Cl}_{6}$, the energetics for the formation pathway of $\mathrm{Cs}_{2} \mathrm{NaBi}_{1-x} \mathrm{In}_{x} \mathrm{Cl}_{6}$ can be written as,

$$
1-x \mathrm{Cs}_{2} \mathrm{NaBiCl}_{6}+x \mathrm{Cs}_{2} \mathrm{NaInCl}_{6} \rightarrow \mathrm{Cs}_{2} \mathrm{NaBi}_{1-x} \mathrm{In}_{x} \mathrm{Cl}_{6}
$$

where $\mathrm{Cs}_{2} \mathrm{NaBiCl}_{6}$ and $\mathrm{Cs}_{2} \mathrm{NaInCl}_{6}$ belong to the stable perovskite material. Figure $1 \mathrm{f}$ shows the formation energy per atom of $\mathrm{Cs}_{2} \mathrm{NaBi}_{1-x} \mathrm{In}_{x} \mathrm{Cl}_{6}$ as a function of $x$. For $\mathrm{Cs}_{2} \mathrm{NaBi}_{1-x} \mathrm{In}_{x} \mathrm{Cl}_{6}$, the formation energies are positive, and present a quadratic relations as a function of $x$, meaning that the solid solutions have less stable nature than $\mathrm{Cs}_{2} \mathrm{NaBiCl}_{6}$ or $\mathrm{Cs}_{2} \mathrm{NaInCl}_{6}$, due to the strain energy from the size mismatch of $\mathrm{Bi}$ and In constituents. However, the energies for the solid solutions are less than $1 \mathrm{meV} /$ atom higher than the single perovskites, relatively small enough to be overcame by the mixing entropy, suggesting that $\mathrm{Cs}_{2} \mathrm{NaBi}_{1-x} \mathrm{In}_{x} \mathrm{Cl}_{6}$ could be stabilized at medium temperature. The result here also verified that the composition at $x=$ 0.5 possess the highest formation energy, which also supported that we can hardly to obtain the pure phase of $\mathrm{Cs}_{2} \mathrm{NaBi}_{1-x} \mathrm{In}_{x} \mathrm{Cl}_{6}(x=0.5)$ mentioned above.

To demonstrate the optical band gaps for these materials, the UV-Vis diffuse reflection data have been collected. The spectrum of $\mathrm{Cs}_{2} \mathrm{NaBi}_{1-x} \mathrm{In}_{x} \mathrm{Cl}_{6}$ shows a high reflectance in the visible range, and the band gap estimation in the $\mathrm{Cs}_{2} \mathrm{NaBi}_{1-x} \mathrm{In}_{x} \mathrm{Cl}_{6}$ can be estimated according to eq $1^{[14]}$

$$
\left[F\left(R_{\infty}\right) h v\right]^{\mathrm{n}}=A\left(h v-E_{g}\right)
$$

where $h v$ is the photon energy; $A$ is a proportional constant; $E_{g}$ is the value of the band gap; $\mathrm{n}$ $=2$ for a direct transition or $1 / 2$ for an indirect transition; and $F\left(R_{\infty}\right)$ is the Kubelka-Munk function defined as ${ }^{[15]}$

$$
F\left(R_{\infty}\right)=(1-R)^{2} / 2 R=K / S
$$

where $R, K$, and $S$ are the reflection, absorption, and scattering coefficient, respectively. In Figure $2 \mathrm{~b}$, we can deduce that $\mathrm{Cs}_{2} \mathrm{NaBiCl}_{6}$ exhibits the characteristics of an indirect band gap 


\section{WILEY-VCH}

semiconductor with a shallow absorption at an edge value of $3.41 \mathrm{eV}$ (indirect band gap) followed by an increase in absorption edge at $3.73 \mathrm{eV}$ (direct band gap). Furthermore, the linear regions of the Tauc plot of $\left(F\left(R_{\infty}\right) h v\right]^{1 / 2} v s . h v$ indicate the anticipative phonon-assisted processes, with transitions at 3.41 and $3.73 \mathrm{eV}$ due to the absorption and emission of a phonon, respectively. And the indirect band gap of this material can be estimated as $3.41 \mathrm{eV}$. As $\mathrm{In}^{3+}$ ions were doped into the $\mathrm{Cs}_{2} \mathrm{NaBiCl}_{6}$ host, the first absorption edge becomes larger while the later absorption edge becomes smaller. However, $\mathrm{Cs}_{2} \mathrm{NaInCl}_{6}$ possesses the characteristics of direct band gaps with absorption edge at $3.73 \mathrm{eV}$, from the corresponding Tauc plot of $\left(F\left(R_{\infty}\right) h v\right]^{2} v s$. $h v$. To observe the change of band gap value clearly, the first and later absorption edge are plotted in Figure 2c. This change can be mainly divided into two parts, and the mutation point appears at about $x=0.5$, and the reason and their corresponding explanation will be discussed below.

To investigate the electrical and optical contributions of the two end members for the solid solution of $\mathrm{Cs}_{2} \mathrm{NaBi}_{1-x} \mathrm{In}_{x} \mathrm{Cl}_{6}$, we performed the first-principles calculations for $\mathrm{Cs}_{2} \mathrm{NaBiCl}_{6}$ and $\mathrm{Cs}_{2} \mathrm{NaInCl}_{6}$. Figure $3 \mathrm{a}$ and $3 \mathrm{~b}$ show the calculated band structures of primitive $\mathrm{Cs}_{2} \mathrm{NaBiCl}_{6}$ and $\mathrm{Cs}_{2} \mathrm{NaInCl}_{6}$ with $\mathrm{SOC}$ included. For $\mathrm{Cs}_{2} \mathrm{NaBiCl}_{6}$, as shown in Figure 3a, the Bi $6 s$ orbital is lower in energy and the lone pair $s$ state is deep inside the valence band, so the valence band maximum (VBM) consists mainly of the $\mathrm{Cl} 3 p$ orbitals and is located at $W$ point where the coupling between $\mathrm{Cl} 3 p$ and $\mathrm{Bi} 6 s$ is strong and pushes the $\mathrm{Cl}$ $3 p$ state up. whereas the conduction band minimum (CBM) consists mainly of Bi $6 p$ and some $\mathrm{Na} 4 s$ orbitals and is located at $\Gamma$ point, because the $s-p$ repulsion between the $\mathrm{Na} 4 s$ and $\mathrm{Bi} 6 p$ orbitals pushes the CBM state at $\Gamma$ point to a lower energy, resulting in an indirect band gap. The gap is calculated to be $3.00 \mathrm{eV}$, which corresponds to our experimental measurements of $3.41 \mathrm{eV}$. Noting that a direct transition of $3.23 \mathrm{eV}$ would also be possible at $L$ point, this transition corresponds to and is consistent with the experimental feature at $3.73 \mathrm{eV}$ (see Figure 2b). The energy distinction between experimental observation and theoretical 


\section{WILEY-VCH}

calculation is understandable because DFT-PBE calculation underestimates the band gap. However, such distinction would not influence our qualitative analysis on the electronic and optical properties of $\mathrm{Cs}_{2} \mathrm{NaBi}_{1-x} \mathrm{In}_{x} \mathrm{Cl}_{6}$. For $\mathrm{Cs}_{2} \mathrm{NaInCl}_{6}$, as shown in Figure $3 b$, The VBM and $\mathrm{CBM}$ are originated mainly from the $\mathrm{Cl} 3 p$ and In $5 s$ orbitals, respectively, and both are located at $\Gamma$ point, resulting in a direct band gap of $2.96 \mathrm{eV}$. Comparing with the PBE calculations of $\mathrm{Cs}_{2} \mathrm{NaBiCl}_{6}$ and $\mathrm{Cs}_{2} \mathrm{NaInCl}_{6}$ elsewhere ${ }^{[16]}$, the band gap of $\mathrm{Cs}_{2} \mathrm{NaBiCl}_{6}$ with SOC is $\sim 0.8 \mathrm{eV}$ lower than PBE calculations, and the CBM has been located at $\Gamma$ point rather than $L$ point. This is mainly due to the SOC induced splitting of the $\mathrm{Bi} 6 p$ conduction bands, pushing one of the Bi $6 p$ orbital towards $\mathrm{VBM}$ and reducing the band gap. For $\mathrm{Cs}_{2} \mathrm{NaInCl}_{6}$, the band gap wasn't influenced by whether or not SOC is included, as SOC effect on In $5 s$ orbital is much smaller than that on Bi $6 p$ orbital that furthermore can split by SOC. Noting that the first valence band is rather flat along the $\Gamma-X$ direction, $\mathrm{Cs}_{2} \mathrm{NaInCl}_{6}$ could have very different transport properties for electrons and holes.

We further analyze the optical transitions in $\mathrm{Cs}_{2} \mathrm{NaBi}_{1-x} \mathrm{In}_{x} \mathrm{Cl}_{6}$ solid solutions, as shown in Figure 3c. For $\mathrm{Cs}_{2} \mathrm{NaBiCl}_{6}$, two optical transitions between band edge states are presented, which are correspond to the direct transition at $L$ point and that at $\Gamma$ point. The transitions between band edges could occur unless the VBM and CBM have different parities. ${ }^{[16-17]}$ However, the parity shown in Figure $3 \mathrm{~b}$ for $\mathrm{Cs}_{2} \mathrm{NaInCl}_{6}$ indicates an even parity for both VBM and $\mathrm{CBM}$ states, resulting that $\mathrm{Cs}_{2} \mathrm{NaInCl}_{6}$ unable to break parity-forbidden transitions. The optical allowed transition in $\mathrm{Cs}_{2} \mathrm{NaInCl}_{6}$ starts at $3.24 \mathrm{eV}$ (see red arrow line in Figure $3 \mathrm{~b}$ ) which corresponds to the measured experimental feature at $3.73 \mathrm{eV}$ (see Figure 2b). Such parity forbidden effect is also observed in $\operatorname{In}_{2} \mathrm{O}_{3}$, where the optical absorption is $\sim 0.81 \mathrm{eV}$ higher in energy than the fundamental band gap ${ }^{[18]}$, showing an intrinsic feature of ordered to disordered compounds. Comparing with $\mathrm{Cs}_{2} \mathrm{NaBiCl}_{6}, \mathrm{Cs}_{2} \mathrm{NaInCl}_{6}$ shows obvious drop down in absorption intensity, due to the electronic properties of $\mathrm{Cs}_{2} \mathrm{NaInCl}_{6}$. As the cell symmetry of $\mathrm{Cs}_{2} \mathrm{NaInCl}_{6}$ is reduced by cation transmutation, and the band edge states are derived from 


\section{WILEY-VCH}

the 'fold-in' bands of the ideal $\mathrm{ABX}_{3}$ primitive cell, the direct band gap of $\mathrm{Cs}_{2} \mathrm{NaInCl}_{6}$ is authentic. For $\mathrm{Cs}_{2} \mathrm{NaBi}_{1-x} \mathrm{In}_{x} \mathrm{Cl}_{6}$, the absorption intensity decreases as the ratio of $\mathrm{In}^{3+}$ increases, showing a combination effect of absorption on $\mathrm{Cs}_{2} \mathrm{NaBi}_{1-x} \mathrm{In}_{x} \mathrm{Cl}_{6}$. For $x$ over than 0.5 , the absorption intensity decrease dramatically, which is caused mainly by the domination of $\mathrm{In}^{3+}$, the optical absorption presents more effect of $\mathrm{Cs}_{2} \mathrm{NaInCl}_{6}$ (with parity forbidden effect) than $\mathrm{Cs}_{2} \mathrm{NaBiCl}_{6}$.

To search for a suitable metal halide double perovskite for optical and optoelectronic properties in the visible region is still going on, thus the $\mathrm{Mn}^{2+}$ doping effect in the $\mathrm{Cs}_{2} \mathrm{NaBi}_{1-x} \mathrm{In}_{x} \mathrm{Cl}_{6}$ solid solutions have been investigated. ${ }^{[12]}$ Variations in the excitation (PLE) and emission (PL) spectra of the $\mathrm{Cs}_{2} \mathrm{NaBi}_{1-x} \mathrm{In}_{x} \mathrm{Cl}_{6}: 0.03 \mathrm{Mn}^{2+}(x=0,0.1,0.2,0.3,0.4,0.7,0.9$ and 1.0) samples depending on the $x$ values (different $\mathrm{Bi} / \mathrm{In}$ ratios) are shown in Figure $4 \mathrm{a}$. The results illustrate that all of the PLE spectra of the materials consists of three bands around at 297, 358 and $429 \mathrm{~nm}$, corresponding to the spin and parity forbidden transitions in the $3 \mathrm{~d}^{5}$ electron configuration of $\mathrm{Mn}^{2+}$ from the ground state ${ }^{6} \mathrm{~A}_{1}\left({ }^{6} \mathrm{~S}\right)$ to excited states of ${ }^{4} \mathrm{~T}_{1}\left({ }^{4} \mathrm{P}\right),{ }^{4} \mathrm{~T}_{2}\left({ }^{4} \mathrm{D}\right)$ and ${ }^{4} \mathrm{~T}_{2}\left({ }^{4} \mathrm{G}\right)$, respectively. Furthermore, the excitation bands of all the samples with various $x$ values have a blue-shift tendency from $358 \mathrm{~nm}$ to $346 \mathrm{~nm}$ as the $\mathrm{In}^{3+}$ concentration increase from $x=0$ to $x=0.9$. A red shift of the $\mathrm{Mn}^{2+}$ excitation would be expected to happen in $\mathrm{Cs}_{2} \mathrm{NaBi}_{1-x} \mathrm{In}_{x} \mathrm{Cl}_{6}: 0.03 \mathrm{Mn}^{2+}$ with increasing $\mathrm{In}^{3+} / \mathrm{Bi}^{3+}$ ratio due to the stronger crystal field of $\mathrm{In}^{3+}$ as compared with that of $\mathrm{Bi}^{3+}$. However, the observed blue-shifted tendency in this system may be originated from ions of different radii having different compression on the bond length. Therefore, a structural changes model with varying $\mathrm{In}^{3+}$ content is proposed herein to explain the blue-shift phenomenon of the excitation spectra, which is shown in Figure $4 \mathrm{~b}$. As far as $\mathrm{Mn}^{2+}$ ion is sandwiched between $\mathrm{Bi}^{3+} / \mathrm{In}^{3+}$ ions, therefore big $\mathrm{Bi}^{3+}$ ions compress $d(\mathrm{Mn}-\mathrm{Cl})$ bond length more hardly than small $\mathrm{In}^{3+}$ ions. In the $\left(\mathrm{In}^{3+}\right.$-free) $\mathrm{Cs}_{2} \mathrm{NaBiCl}_{6}: 0.03 \mathrm{Mn}^{2+}$ compound, the large radii of $\mathrm{Bi}^{3+}$ ions lead to stressful compression of neighboring $d(\mathrm{Mn}-\mathrm{Cl})$ bonds. With increasing $\mathrm{In}^{3+}$ concentration, some stress 


\section{WILEY-VCH}

would be released due to the smaller ionic radius of $\operatorname{In}^{3+}$ (at $0.8 \AA$ ) than of $\mathrm{Bi}^{3+}$ (at $1.03 \AA$ ), and the bond length of $d(\mathrm{Mn}-\mathrm{Cl})$ would be increased. The crystal filed splitting of $\mathrm{Mn}^{2+}$ would in turn weaken on the basis of this model, and emission peaks would become blue-shifted. This model can well explain the blue-shift behavior in $\mathrm{Cs}_{2} \mathrm{NaBiCl}_{6}: 0.03 \mathrm{Mn}^{2+}$ solid solutions to a certain extent. In spite of the increasing in the bond length of $d(\mathrm{Mn}-\mathrm{Cl})$, the average bond length of $d(\mathrm{Na} / \mathrm{Bi} / \mathrm{In} / \mathrm{Mn}-\mathrm{Cl})$ decreases in $\mathrm{Cs}_{2} \mathrm{NaBi}_{1-x} \mathrm{In}_{x} \mathrm{Cl}_{6}: 0.03 \mathrm{Mn}^{2+}$ compounds with increasing $\mathrm{In}^{3+}$ content. This is because the contribution of $d(\mathrm{Bi}-\mathrm{Cl})$ to the average bond length lessens with increasing $\mathrm{In}^{3+}$, as can be seen in Figure $4 \mathrm{~b}$, while the contribution of $d(\mathrm{Mn}-\mathrm{Cl})$ to the average bond length is very small. So the average bond length $d(\mathrm{Na} / \mathrm{Bi} / \mathrm{In} / \mathrm{Mn}-\mathrm{Cl})$ decreases along with decreasing cell volume and increasing $\mathrm{In}^{3+}$ content. Upon the excitation of $358 \mathrm{~nm}$, all of the samples exhibit the orange-yellow emission, which can be ascribed to ${ }^{4} \mathrm{~T}_{1}\left({ }^{4} \mathrm{G}\right)-{ }^{6} \mathrm{~A}_{1}\left({ }^{6} \mathrm{~S}\right)$ transitions of $\mathrm{Mn}^{2+}$. At the same time, the emission intensities were gradually increased and maximized at the $\mathrm{In}^{3+}$ concentration of 0.2. And the measured internal quantum efficiency (QE) of $\mathrm{Cs}_{2} \mathrm{NaBi}_{0.8} \mathrm{In}_{0.2} \mathrm{Cl}_{6}: 0.03 \mathrm{Mn}^{2+}$ is $56 \%$.

Figure $4 \mathrm{c}$ represent a digital photograph of single crystal of $\mathrm{Cs}_{2} \mathrm{NaBiCl}_{6}: 0.03 \mathrm{Mn}^{2+}$ and $\mathrm{Cs}_{2} \mathrm{NaInCl}_{6}$ under a fluorescence microscope, with characteristic gray transparent color indicating a band gap in the invisible range. When the crystal growth time via hydrothermal method is prolonged to $36 \mathrm{~h}$, which enabled the formation of the millimeter-sized regular octahedron single crystals with the edge length of around $0.5 \mathrm{~mm}$. In addition, single crystal of $\mathrm{Cs}_{2} \mathrm{NaBiCl}_{6}: 0.03 \mathrm{Mn}^{2+}$ exhibits orange-yellow luminescence owing to the characteristics of $\mathrm{Mn}^{2+}$. Furthermore, Figure $4 \mathrm{~d}$ presents the room temperature decay curves of $\mathrm{Mn}^{2+}$ luminescence in $\mathrm{Cs}_{2} \mathrm{NaBi}_{1-x} \mathrm{In}_{x} \mathrm{Cl}_{6}: 0.03 \mathrm{Mn}^{2+}(x=0,0.1,0.2,0.3,0.4,0.7$ and 0.9). All the decay curves can be well fitted with a second order exponential equation: ${ }^{[3 b]}$

$$
I(t)=A_{1} \exp \left(-t / \tau_{1}\right)+A_{2} \exp \left(-t / \tau_{2}\right)
$$




\section{WILEY-VCH}

where $I$ is the luminescence intensity, $A_{l}$ and $A_{2}$ are constants, $\tau$ is the time, $\tau_{1}$ and $\tau_{2}$ are rapid and slow lifetimes for exponential components, respectively. On this basis, the effective lifetime constant $\left(\tau^{*}\right)$ can be calculated as:

$$
\tau^{*}=\left(A_{1} \tau_{1}^{*}+A_{2} \tau_{2}^{*}\right) /\left(A_{1} \tau_{1}+A_{2} \tau_{2}\right)
$$

Based on the decay curves in Figure $4 d$ and fitting Eq. (4) and the calculation Eq. (5), the effective decay time $\left(\tau^{*}\right)$ were calculated to be $0.34 \mathrm{~ms}, 0.37 \mathrm{~ms}, 0.39 \mathrm{~ms}, 0.40 \mathrm{~ms}, 0.42 \mathrm{~ms}$, $0.46 \mathrm{~ms}$ and $0.52 \mathrm{~ms}$ for $\mathrm{Cs}_{2} \mathrm{NaBi}_{1-x} \mathrm{In}_{x} \mathrm{Cl}_{6}: 0.03 \mathrm{Mn}^{2+}$ with $x=0,0.1,0.2,0.3,0.4,0.7$ and 0.9 , respectively. It can be clearly found that the lifetime values increased with the increasing content of $\mathrm{In}^{3+}$ ions. We proposed that the phase structures become more rigid with a high symmetry compared to the initial $\mathrm{Cs}_{2} \mathrm{NaBiCl}_{6}$ phase, so that the energy transfer possibility among $\mathrm{Mn}^{2+}$ decreases, which in turn decrease the possible non-radiative transition and lead to the increasing lifetime values in such a system.

Effect of $\mathrm{Mn}^{2+}$ contribution on the electronic structure of $\mathrm{Cs}_{2} \mathrm{NaBi}_{1-x} \mathrm{In}_{x} \mathrm{Cl}_{6}: \mathrm{Mn}^{2+}$ solid solution has been studied, and we adopted the $\mathrm{Cs}_{2} \mathrm{Na}_{0.75} \mathrm{Mn}_{0.5} \mathrm{Bi}_{0.75-x} \mathrm{In}_{x} \mathrm{Cl}_{6}$ structures based on the super cell structure shown in Figure 1c, where two cations (one $\mathrm{Na}^{+}$and one $\mathrm{Bi}^{3+} / \mathrm{In}^{3+}$ ) are replaced by $\mathrm{Mn}^{2+}$ to ensure the valence state of $\mathrm{Mn}^{2+}$. All $\mathrm{Mn}^{2+}$-doped structures for different $\mathrm{Bi}^{3+} / \mathrm{In}^{3+}$ ratios are chosen according to the lowest static total energy. Figure 5a gives the formation energies for $\mathrm{Cs}_{2} \mathrm{Na}_{0.75} \mathrm{Mn}_{0.5} \mathrm{Bi}_{0.75-x} \mathrm{In}_{x} \mathrm{Cl}_{6}$, with respect to the stable perovskite materials $\mathrm{CsMnCl}_{3}, \mathrm{Cs}_{2} \mathrm{NaBiCl}_{6}$ and $\mathrm{Cs}_{2} \mathrm{NaInCl}_{6}$, showing that the solid solutions are higher in energy than their perovskite constituents by formation energies up to $\sim 7.60 \mathrm{meV} /$ atom (see the red curve in Figure 5a). This is understandable because the internal strain energy from the size mismatch between small $\mathrm{Mn}^{2+}$ and large $\mathrm{Na}^{+}$or $\mathrm{Bi}^{3+} / \mathrm{In}^{3+}$ ions could inevitable raise the formation energies for these structures. However, considering $\mathrm{Cs}_{2} \mathrm{Na}_{0.75} \mathrm{Mn}_{0.5} \mathrm{Bi}_{0.75-\mathrm{x}} \mathrm{In}_{\mathrm{x}} \mathrm{Cl}_{6}$ as a mixture of $\mathrm{Cs}_{2} \mathrm{Na}_{0.75} \mathrm{Mn}_{0.5} \mathrm{Bi}_{0.75} \mathrm{Cl}_{6}$ and $\mathrm{Cs}_{2} \mathrm{Na}_{0.75} \mathrm{Mn}_{0.5} \mathrm{In}_{0.75} \mathrm{Cl}_{6}$, the $\mathrm{Cs}_{2} \mathrm{Na}_{0.75} \mathrm{Mn}_{0.5} \mathrm{Bi}_{0.75-\mathrm{x}} \mathrm{In}_{\mathrm{x}} \mathrm{Cl}_{6}$ composite shows negative mixing energy (see the blue curve in Figure 5a). Compared with the formation energy variation without $\mathrm{Mn}^{2+}$ doping in Figure 1f, 


\section{WILEY-VCH}

the change of sign in the energy (positive for Figure 1f, negative for mixing energy in Figure 5a) indicates that the inclusion of $\mathrm{Mn}^{2+}$ dopants in the solid solutions could promote the mixing of $\mathrm{Bi}^{3+}$ and $\mathrm{In}^{3+}$ ions as $\mathrm{Mn}^{2+}$ could acts as an absorber of the internal strain arising from $\mathrm{Bi}^{3+} / \mathrm{In}^{3+}$ mixing. Although the super cell structures adopted in our atomistic first-principles calculations could not exactly mimic the fully random solid solutions in our experiments, we attempt to analyze the band edge states that are related to PL. Figure 5b and $5 \mathrm{c}$ show the calculated density of state (DOS) for $\mathrm{Cs}_{2} \mathrm{Na}_{0.75} \mathrm{Mn}_{0.5} \mathrm{Bi}_{0.75} \mathrm{Cl}_{6}$ and $\mathrm{Cs}_{2} \mathrm{Na}_{0.75} \mathrm{Mn}_{0.5} \mathrm{In}_{0.75} \mathrm{Cl}_{6}$ (The DOS of $\mathrm{Cs}_{2} \mathrm{Na}_{0.75} \mathrm{Mn}_{0.5} \mathrm{Bi}_{0.5} \mathrm{In}_{0.25} \mathrm{Cl}_{6}$ and $\mathrm{Cs}_{2} \mathrm{Na}_{0.75} \mathrm{Bi}_{0.25} \mathrm{In}_{0.5} \mathrm{Cl}_{6}$ are shown in Figure S2). For $\mathrm{Cs}_{2} \mathrm{Na}_{0.75} \mathrm{Mn}_{0.5} \mathrm{Bi}_{0.75-x} \mathrm{In}_{x} \mathrm{Cl}_{6}$, the upper valence bands are mainly contributed by $\mathrm{Cl} 3 p$ orbitals analogous to $\mathrm{Cs}_{2} \mathrm{NaBi}(\mathrm{In}) \mathrm{Cl}_{6}$, while the $\mathrm{VBM}$ state is mainly from Mn $3 d$ orbitals. The CBM state is mainly contributed by Bi $6 p$ or In $5 s$, with a small amount of Mn $3 d$ state mixed in. Meanwhile, the band gap for $\mathrm{Mn}^{2+}$-doped $\mathrm{Cs}_{2} \mathrm{NaBi}(\mathrm{In}) \mathrm{Cl}_{6}$ decreases from $3.00(2.96) \mathrm{eV}$ to $2.28(2.22) \mathrm{eV}$, corresponding to optical wavelength of 544 $\mathrm{nm}(559 \mathrm{~nm})$ that is close to the experimental wavelength of the PL peak. The decreasing band gap is mainly caused by the appearance of the $\mathrm{Mn} 3 d$ state above the $\mathrm{Cl} 3 p$ state (see e.g. Figure $5 \mathrm{~b}$ and Figure 5c). The appearance of Mn $3 d$ state in both VBM and CBM hints that the PL in the solid solutions is related to the $d-d$ transitions of $\mathrm{Mn}^{2+}$, as indicated in Figure 4a. Although the amount of $\mathrm{Mn} 3 d$ state at $\mathrm{CBM}$ in $\mathrm{Cs}_{2} \mathrm{Na}_{0.75} \mathrm{Mn}_{0.5} \mathrm{In}_{0.75} \mathrm{Cl}_{6}$ (see Figure $5 \mathrm{c}$ ) is much smaller (but not vanishing) than that in $\mathrm{Cs}_{2} \mathrm{Na}_{0.75} \mathrm{Mn}_{0.5} \mathrm{Bi}_{0.75} \mathrm{Cl}_{6}$ (see Figure $5 \mathrm{~b}$ ), the fact that $\mathrm{PL}$ vanishes as the $\mathrm{Bi}^{3+} / \mathrm{In}^{3+}$ ratios approaches zero (see Figure 4a) hints that the major component (Bi $6 p / \mathrm{In} 5 s$ ) of CBM could affect the PL process. The sharp comparison of PL intensity in $\mathrm{Cs}_{2} \mathrm{Na}_{0.75} \mathrm{Mn}_{0.5} \mathrm{Bi}_{0.75} \mathrm{Cl}_{6}$ (rather strong) and $\mathrm{Cs}_{2} \mathrm{Na}_{0.75} \mathrm{Mn}_{0.5} \mathrm{In}_{0.75} \mathrm{Cl}_{6}$ (vanishing) coincides with the opposite parities of the $\mathrm{Bi} 6 p / \mathrm{In} 5 s$ dominated CBM state in $\mathrm{Cs}_{2} \mathrm{NaBiCl}_{6} / \mathrm{Cs}_{2} \mathrm{NaInCl}_{6}$ as shown in Figure $3 \mathrm{a}$ and Figure $3 \mathrm{~b}$ (showing a parity-forbidden optical transition). As $\mathrm{Mn} 3 d$ state is a minor component of CBM mixed into the major Bi $6 p / \mathrm{In} 5 s$ state, the strong hybridization of $\mathrm{Bi} 6 p / \mathrm{In} 5 s$ state with $\mathrm{Mn} 3 d$ state induces bulk 


\section{WILEY-VCH}

electronic-structure/symmetry (e.g. band parity in bulk crystalline symmetry) features in the photoluminescence of $\mathrm{Mn}^{2+}$ dopants. For $\mathrm{Bi} / \mathrm{In}$ solid solutions, as shown in Figure $\mathrm{S} 2$, the $\mathrm{CBM}$ is mainly contributed by $\mathrm{Bi} 6 p$ rather than In $5 s$, indicating that the solid solutions perform dominant character of Bi constituent on optical properties, which is in consistent with experimental observations that pure In sample $(x=1.0$ in Figure $4 a)$ performs different PL properties from Bi involved samples.

\section{Conclusion}

In summary, we have prepared the new substituted halide double perovskites, $\mathrm{Cs}_{2} \mathrm{NaBi}_{1-x} \mathrm{In}_{x} \mathrm{Cl}_{6}: \mathrm{Mn}^{2+}$, and the phase formation behavior and doped $\mathrm{Mn}^{2+}$ photoluminescence has been studied. By gradually substitution of $\mathrm{Bi}^{3+}$ with $\mathrm{In}^{3+}$, the cubic lattice constants of the solid solutions decrease linearly and the band gap changes from indirect band gap to direct band gap, which are both confirmed from experimental observations and theoretical calculations. For $\mathrm{Cs}_{2} \mathrm{NaBi}_{1-x} \mathrm{In}_{x} \mathrm{Cl}_{6}$, the absorption intensity decreases as the ratio of $\mathrm{In}^{3+}$ increases, showing a combination effect of absorption on $\mathrm{Cs}_{2} \mathrm{NaBi}_{1-x} \mathrm{In}_{x} \mathrm{Cl}_{6}$. When doped with $\mathrm{Mn}^{2+}$, the double perovskites yield a strong orange-yellow colored emission except $x=1.0$, consistent with the DOS analysis, and the excitation peaks were blue shifted depending on the $\mathrm{Bi}^{3+} / \mathrm{In}^{3+}$ ratios, which was ascribed to the compression effect on the bond lengths from substituted ions. The successful adjustment of band gap and $\mathrm{Mn}^{2+}$-doped photoluminescence in the $\mathrm{Cs}_{2} \mathrm{NaBi}_{1-x} \mathrm{In}_{x} \mathrm{Cl}_{6}$ crystals demonstrated here will expand the utility and understanding of the optoelectronic character within the lead-free halide double perovskite family.

\section{Experimental Section}

Materials and Preparation: All the chemicals were commercially purchased and used without further purification. $\mathrm{Cs}_{2} \mathrm{NaBi}_{1-x} \mathrm{In}_{x} \mathrm{Cl}_{6}: \mathrm{Mn}^{2+}(x=0,0.1,0.2,0.3,0.4,0.7,0.9$ and 1.0) crystals were synthesized by the hydrothermal method in a stainless steel Parr autoclave using $\mathrm{CsCl}$ (99.99\%, Aladdin), $\mathrm{NaCl}$ (99.99\%, Aladdin), $\mathrm{BiCl}_{3}$ (99.99\%, Aladdin), $\mathrm{InCl}_{3}$ (99.99\%, 


\section{WILEY-VCH}

Aladdin), and a certain amount of $\mathrm{MnCl}_{2}$ (99\%, Aladdin) in $\mathrm{HCl}$ acid solution (A. R., Beijing Chemical Works). A white powder precipitated from solution upon heating at $453 \mathrm{~K}$ for 12 h. This solid was filtered out and then washed with ethanol and finally dried under reduced pressure overnight. Large targeted $\mathrm{Cs}_{2} \mathrm{NaBiCl}_{6}: \mathrm{Mn}^{2+}$ and $\mathrm{Cs}_{2} \mathrm{NaInCl}_{6}$ crystals (as shown in Figure 4c) can be also obtained via the same reaction conditions, and herein the hydrothermal synthesis time at $453 \mathrm{~K}$ has been prolonged to $36 \mathrm{~h}$ and then slowly decreased to room temperature.

Characterization: The powder X-ray diffraction (XRD) measurements were conducted on a D8 Advance diffractometer (Bruker Corporation, Germany) operating at $40 \mathrm{kV}$ and $40 \mathrm{~mA}$ with $\mathrm{Cu} \mathrm{K} \alpha$ radiation $(\lambda=0.15406 \AA)$, and the scanning rate was fixed at $4 \% \mathrm{~min}$. The powder diffraction pattern for Rietveld analysis was collected with the same diffractometer. The step size of $2 \theta$ was $0.016^{\circ}$, and the counting time was $1 \mathrm{~s}$ per step. Rietveld refinement was performed by using TOPAS 4.2 software. ${ }^{[19]}$ The photographs of single crystal were obtained by a Nikon LV100ND fluorescence microscope. The diffuse reflectance spectra were measured on a UV-Vis-NIR spectrophotometer (SHIMADZU UV-3600) supplied with an integrating sphere. Room temperature photoluminescence excitation (PLE) and emission spectra (PL) were measured on a fluorescence spectrophotometer (F-4600, HITACHI, Japan) with a photomultiplier tube operating at $400 \mathrm{~V}$, and a $150 \mathrm{~W}$ Xe lamp used as the excitation lamp. The room temperature decay curves were obtained using a FLSP9200 fluorescence spectrophotometer (Edinburgh Instruments Ltd., U.K.) with the monitoring wavelength of 358 nm. Quantum efficiency was measured using the integrating sphere on the FLSP920 fluorescence spectrophotometer (Edinburgh Instruments Ltd., U.K.).

Computational method: For theoretical details, first-principles calculations based on density functional theory (DFT) were performed using the Vienna ab-initio simulation package (VASP) code. ${ }^{[20]}$ The projector augmented wave (PAW) potential method was used to describe the interactions between ions and electrons. The exchange-correlation interactions 


\section{WILEY-VCH}

between electrons were treated within the generalized gradient approximation (GGAPBE). ${ }^{[21]}$ The plane wave cut-off energy of $500 \mathrm{eV}$ was used for all structural optimizations and electronic calculations. The $k$-point meshes for different structures were generated according to the Monkhorst-Pack scheme ${ }^{[22]}$ for the Brillouin zones, as $8 \times 8 \times 8$ for primitive $\mathrm{Cs}_{2} \mathrm{NaBi}(\mathrm{In}) \mathrm{Cl}_{6}$, and $5 \times 5 \times 5$ for $\mathrm{Cs}_{2} \mathrm{NaBi}_{1-x} \mathrm{In}_{x} \mathrm{Cl}_{6}$ supercell. Relativistic spin-orbit coupling (SOC) was included in the band structure and optical calculations. The band symmetry and parity analyses are carried out with the QUANTUM ESPRESSO packagebased on GBRV PBE scalar relativistic potentials. ${ }^{[23]}$ For $\mathrm{Mn}^{2+}$-doping calculations, to correct for the self-interaction error in the GGA formalism, a Hubbard U parameter (DFT $+\mathrm{U})^{[24]}$ valued $4.3 \mathrm{eV}^{[25]}$ was included for the Mn ions to treat $3 d$ correlations.

\section{Supporting Information}

Supporting Information is available from the Wiley Online Library or from the author.

\section{Acknowledgements}

The present work was supported by the National Natural Science Foundation of China (Grants 91622125 and 51572023), Natural Science Foundations of Beijing (2172036), and Fundamental Research Funds for the Central Universities (FRF-TP-15-003A2). XZ acknowledges the support from National Key Research and Development Program of China Grant No. 2016YFB0700700.

Received: ((will be filled in by the editorial staff))

Revised: ((will be filled in by the editorial staff)) Published online: ((will be filled in by the editorial staff))

\section{References}

[1] a) S. D. Stranks, G. E. Eperon, G. Grancini, C. Menelaou, M. J. Alcocer, T. Leijtens, L. M. Herz, A. Petrozza, H. J. Snaith, Science. 2013, 342, 341; b) N. J. Jeon, J. H. Noh, Y. C. Kim, W. S. Yang, S. Ryu, S. I. Seok, Nat. Mater. 2014, 13, 897.

[2] X.-G. Zhao, D. Yang, J.-C. Ren, Y. Sun, Z. Xiao, L. Zhang, Joule. 2018, 2, 1662.

[3] a) X. G. Zhao, J. H. Yang, Y. Fu, D. Yang, Q. Xu, L. Yu, S. H. Wei, L. Zhang, J. Am. Chem. Soc. 2017, 139, 2630; b) J. Zhou, X. M. Rong, M. S. Molokeev, X. W. Zhang, Z. G. Xia, J. Mater. Chem. A. 2018, 6, 2346. 


\section{WILEY-VCH}

[4] L. R. Morss, M. Siegal, L. Stenger, N. Edelstein, Inorg. Chem. 1970, 9, 1771.

[5] a) J. Zhou, Z. G. Xia, M. S. Molokeev, X. W. Zhang, D. S. Peng, Q. L. Liu, J. Mater. Chem. A. 2017, 5, 15031; b) E. T. McClure, M. R. Ball, W. Windl, P. M. Woodward, Chem. Mater. 2016, 28, 1348; c) A. H. Slavney, T. Hu, A. M. Lindenberg, H. I. Karunadasa, J. Am. Chem. Soc. 2016, 138, 2138.

[6] a) E. Greul, Michiel L. Petrus, A. Binek, P. Docampo, T. Bein, J. Mater. Chem. A. 2017, 5, 19972; b) J. Luo, S. Li, H. Wu, Y. Zhou, Y. Li, J. Liu, J. Li, K. Li, F. Yi, G. Niu, J. Tang, ACS Photonics. 2017, 5, 398.

[7] a) K.-z. Du, W. Meng, X. Wang, Y. Yan, D. B. Mitzi, Angew. Chem. Int. Ed. 2017, 56, 8158 ; b) T. T. Tran, J. R. Panella, J. R. Chamorro, J. R. Morey, T. M. McQueen, Mater. Horiz. 2017, 4, 688.

[8] a) F. Giustino, H. J. Snaith, ACS Energy Lett. 2016, 1, 1233; b) Q. Sun, J. Wang, W. J. Yin, Y. Yan, Adv. Mater. 2018, 30, e1705901; c) K.-z. Du, X. Wang, Q. Han, Y. Yan, D. B. Mitzi, ACS Energy Letters. 2017, 2, 2486.

[9] W. Liu, Q. Lin, H. Li, K. Wu, I. Robel, J. M. Pietryga, V. I. Klimov, J. Am. Chem. Soc. 2016, 138, 14954.

[10] a) X. Yuan, S. Ji, M. C. De Siena, L. Fei, Z. Zhao, Y. Wang, H. Li, J. Zhao, D. R. Gamelin, Chem. Mater. 2017, 29, 8003; b) D. Parobek, B. J. Roman, Y. Dong, H. Jin, E. Lee, M. Sheldon, D. H. Son, Nano Lett. 2016, 16, 7376.

[11] a) Z. Sun, J. Luo, T. Chen, L. Li, R.-G. Xiong, M.-L. Tong, M. Hong, Adv. Funct. Mater. 2012, 22, 4855; b) D.-W. Fu, H.-L. Cai, Y. Liu, Q. Ye, W. Zhang, Y. Zhang, X.-Y. Chen, G. Giovannetti, M. Capone, J. Li, Science. 2013, 339, 425; c) Y.-M. You, W.-Q. Liao, D. Zhao, H.-Y. Ye, Y. Zhang, Q. Zhou, X. Niu, J. Wang, P.-F. Li, D.-W. Fu, Science. 2017, 357, 306.

[12] a) N. N. K, A. Nag, Chem. Commun (Camb). 2018, 54, 5205; b) F. Locardi, M. Cirignano, D. Baranov, Z. Dang, M. Prato, F. Drago, M. Ferretti, V. Pinchetti, M. Fanciulli, S. Brovelli, L. De Trizio, L. Manna, J. Am. Chem. Soc. 2018, DOI: 10.1021/jacs.8b07983.

[13] L. Morrs, W. Robinson, Acta Crystallographica Section B: Structural Crystallography and Crystal Chemistry 1972, 28, 653.

[14] J. Zhou, Z. G. Xia, M. Bettinelli, Q. L. Liu, RSC Adv. 2016, 6, 2046.

[15] Z. G. Xia, Y. Y. Zhang, M. S. Molokeev, V. V. Atuchin, J. Phys. Chem. C. 2013, 117, 20847.

[16] P. Zhang, J. Yang, S.-H. Wei, J. Mater. Chem. A. 2018, 6, 1809.

[17] W. Meng, X. Wang, Z. Xiao, J. Wang, D. B. Mitzi, Y. Yan, J. Phys. Chem. Lett. 2017, 8, 2999.

[18] A. Walsh, J. L. Da Silva, S. H. Wei, C. Korber, A. Klein, L. F. Piper, A. DeMasi, K. E. Smith, G. Panaccione, P. Torelli, D. J. Payne, A. Bourlange, R. G. Egdell, Phys. Rev. Lett. 2008, 100, 167402.

[19] Bruker AXS, TOPAS V4: General Profile and Structure Analysis Software for Powder Diffrcation Data-User's Manual, Bruker AXS, Karlsruhe, Germany, 2008.

[20] a) G. Kresse, J. Hafner, Phys. Rev. B 1993, 47, 558; b) G. Kresse, J. Furthmüller, Phys. Rev. B. 1996, 54, 11169.

[21] a) P. E. Blöchl, Phys. Rev. B. 1994, 50, 17953; b) J. P. Perdew, K. Burke, M. Ernzerhof, Phys. Rev. Lett. 1996, 77, 3865.

[22] H. J. Monkhorst, J. D. Pack, Phys. Rev. B. 1976, 13, 5188.

[23] a) K. F. Garrity, J. W. Bennett, K. M. Rabe, D. Vanderbilt, Comp. Mater. Sci. 2014, 81, 446; b) P. Giannozzi, S. Baroni, N. Bonini, M. Calandra, R. Car, C. Cavazzoni, D. Ceresoli, G. L. Chiarotti, M. Cococcioni, I. Dabo, J. Phys.: Condens. Matter. 2009, 21, 395502.

[24] V. I. Anisimov, J. Zaanen, O. K. Andersen, Phys. Rev. B. 1991, 44, 943. 


\section{WILEY-VCH}

[25] a) S. P. Ong, V. L. Chevrier, G. Ceder, Phys. Rev. B. 2011, 83; b) F. Zhou, C. A. Marianetti, M. Cococcioni, D. Morgan, G. Ceder, Phys. Rev. B. 2004, 69; c) L. F. J. Piper, N. F. Quackenbush, S. Sallis, D. O. Scanlon, G. W. Watson, K. W. Nam, X. Q. Yang, K. E. Smith, F. Omenya, N. A. Chernova, M. S. Whittingham, J. Phys. Chem. C. 2013, 117, 10383. 


\section{WILEY-VCH}
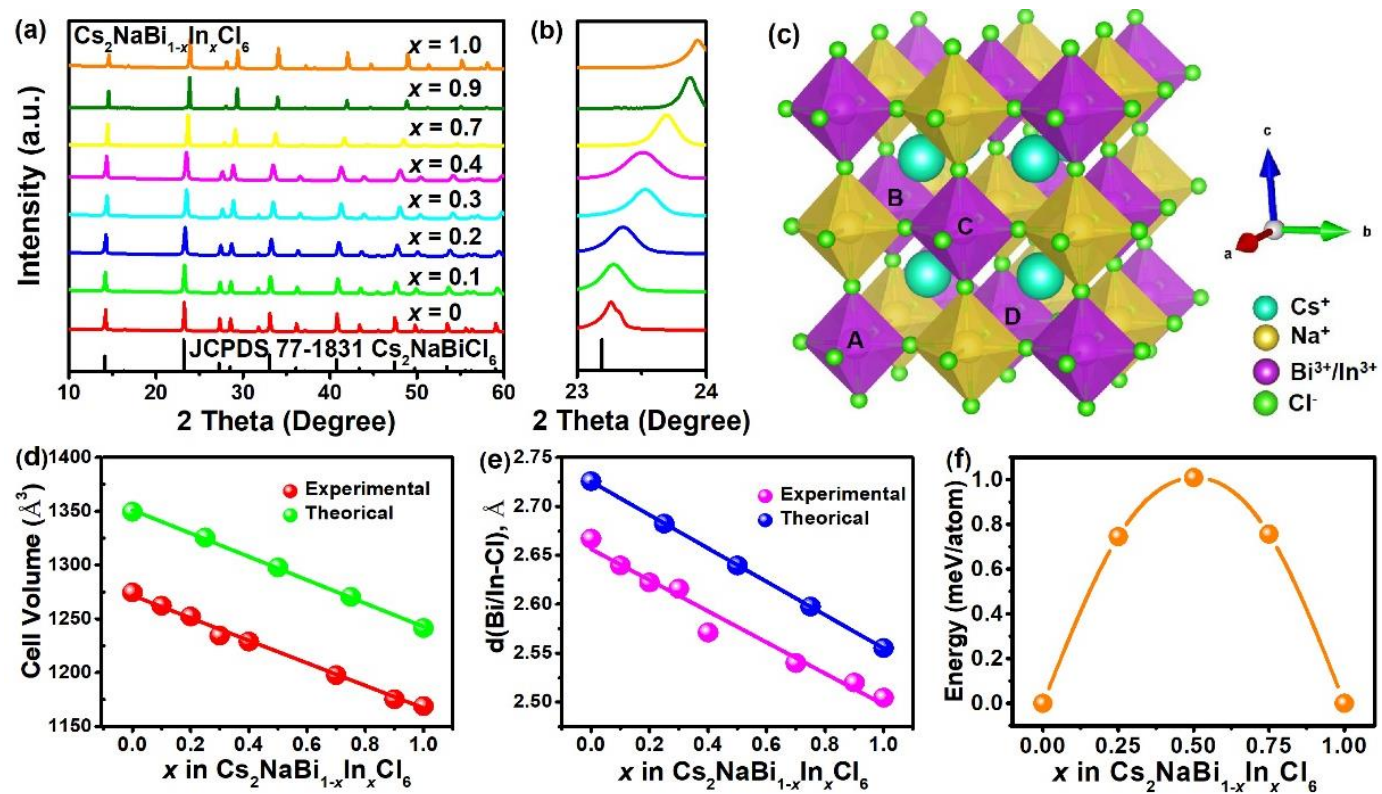

Figure 1. a) XRD patterns and b) selected diffraction peaks near $23^{\circ}$ of the as-prepared $\mathrm{Cs}_{2} \mathrm{NaBi}_{1-x} \mathrm{In}_{x} \mathrm{Cl}_{6}(\mathrm{x}=0,0.1,0.2,0.3,0.4,0.7,0.9$ and 1.0). c) Crystal structure of $\mathrm{Cs}_{2} \mathrm{NaBi}_{1-x} \mathrm{In}_{x} \mathrm{Cl}_{6}$. Observed and calculated d) unit cell volume $V$ and e) bond length $d(\mathrm{Bi} / \mathrm{In}-\mathrm{Cl})$ of $\mathrm{Cs}_{2} \mathrm{NaBi}_{1-x} \mathrm{In}_{x} \mathrm{Cl}_{6}$ samples as a function of $x$. f) Calculated formation energies per atom of $\mathrm{Cs}_{2} \mathrm{NaBi}_{1-x} \mathrm{In}_{x} \mathrm{Cl}_{6}$ as a function of $x$.
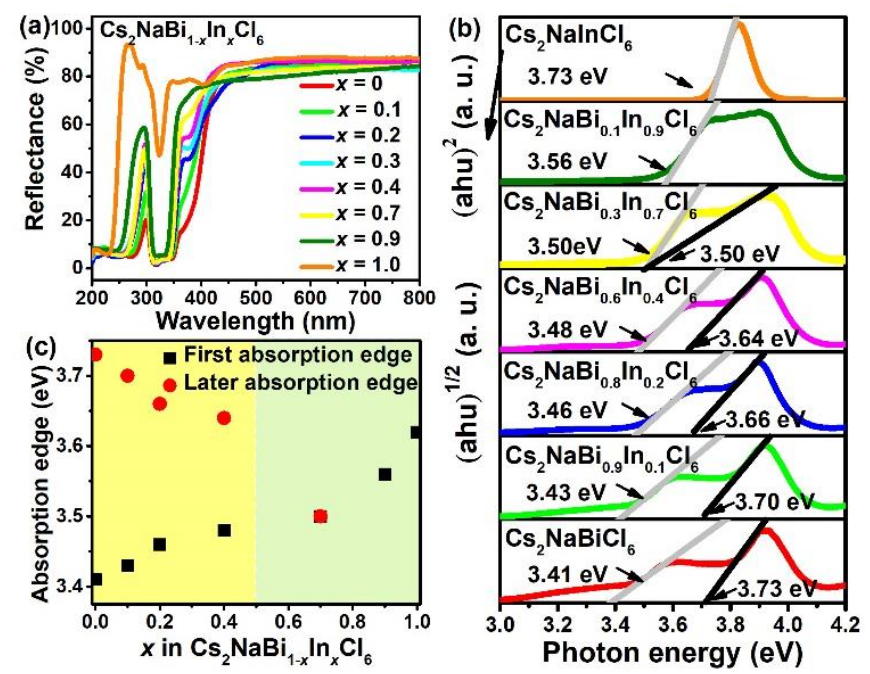

Figure 2. UV-vis diffuse reflectance spectra (a), Tauc plots (b) and (c) the first and later absorption edge for $\mathrm{Cs}_{2} \mathrm{NaBi}_{1-x} \mathrm{In}_{x} \mathrm{Cl}_{6}(x=0,0.1,0.2,0.3,0.4,0.7,0.9$ and 1.0). 


\section{WILEY-VCH}
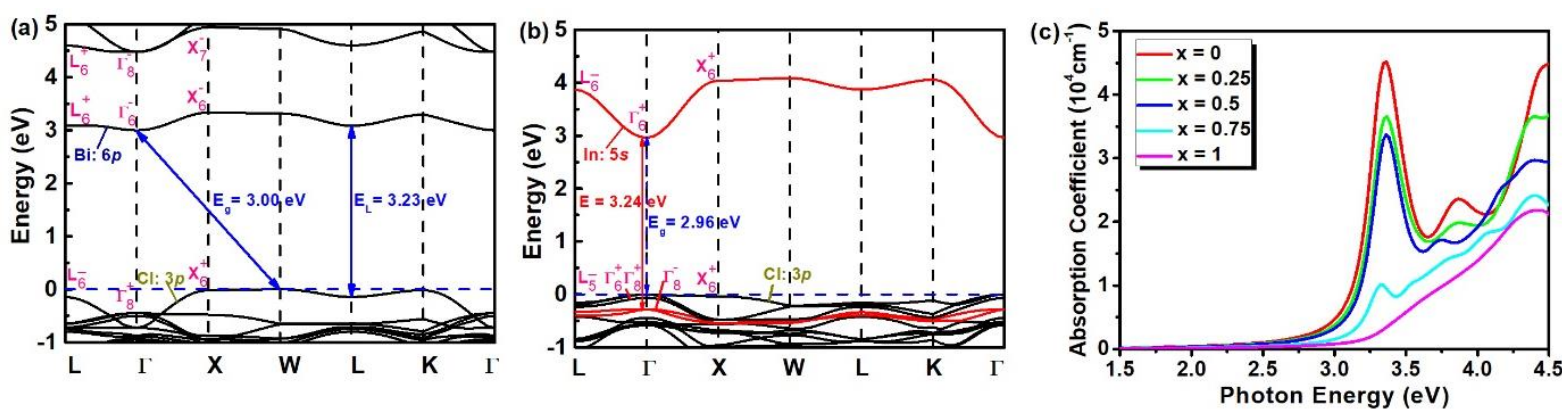

Figure 3. Calculated electronic band structures of $\mathrm{Cs}_{2} \mathrm{NaBiCl}_{6}$ (a) and $\mathrm{Cs}_{2} \mathrm{NaInCl}_{6}$ (b) from the PBE calculations with SOC. (c) Calculated absorption coefficients of $\mathrm{Cs}_{2} \mathrm{NaBi}_{1-x} \mathrm{In}_{x} \mathrm{Cl}_{6}$.
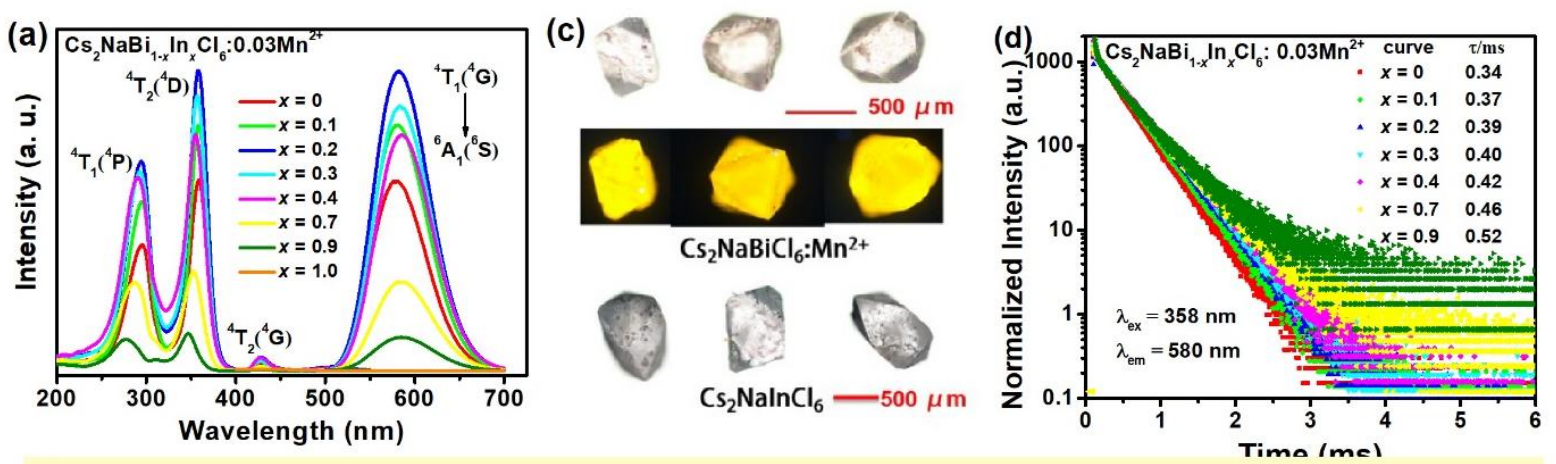

(b) $\mathrm{BiCl}_{6} \mathrm{NaCl}_{6}$

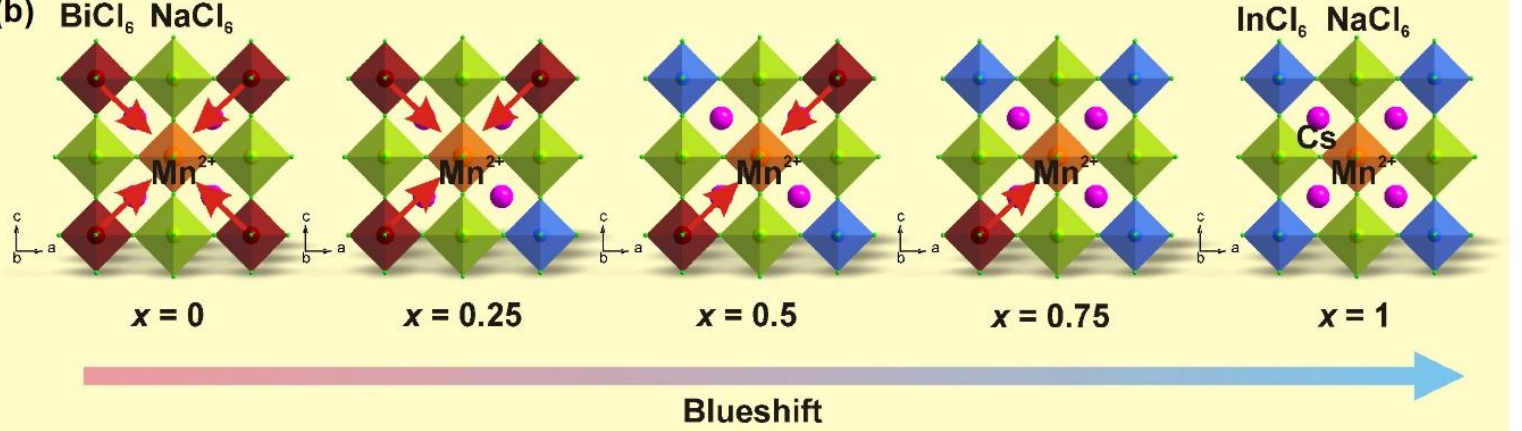

Figure 4. a) PLE and PL spectra of $\mathrm{Cs}_{2} \mathrm{NaBi}_{1-x} \mathrm{In}_{x} \mathrm{Cl}_{6}: 0.03 \mathrm{Mn}^{2+}$; b) single crystals of double perovskites $\mathrm{Cs}_{2} \mathrm{NaBiCl}_{6}: 0.03 \mathrm{Mn}^{2+}$ and $\mathrm{Cs}_{2} \mathrm{NaInCl}_{6}$. c) Schematic figures showing the $\mathrm{Mn}-\mathrm{Cl}$ environment and neighboring-cation effect in $\mathrm{Cs}_{2} \mathrm{NaBi}_{1-x} \mathrm{In}_{x} \mathrm{Cl}_{6}: 0.03 \mathrm{Mn}^{2+}$. And arrows indicate compression of $\mathrm{Mn}-\mathrm{Cl}$ bonds resulting from $\mathrm{Bi}^{3+}$. d) Decay curves of $\mathrm{Cs}_{2} \mathrm{NaBi}_{1-x} \mathrm{In}_{x} \mathrm{Cl}_{6}: 0.03 \mathrm{Mn}^{2+}$. 
WILEY-VCH
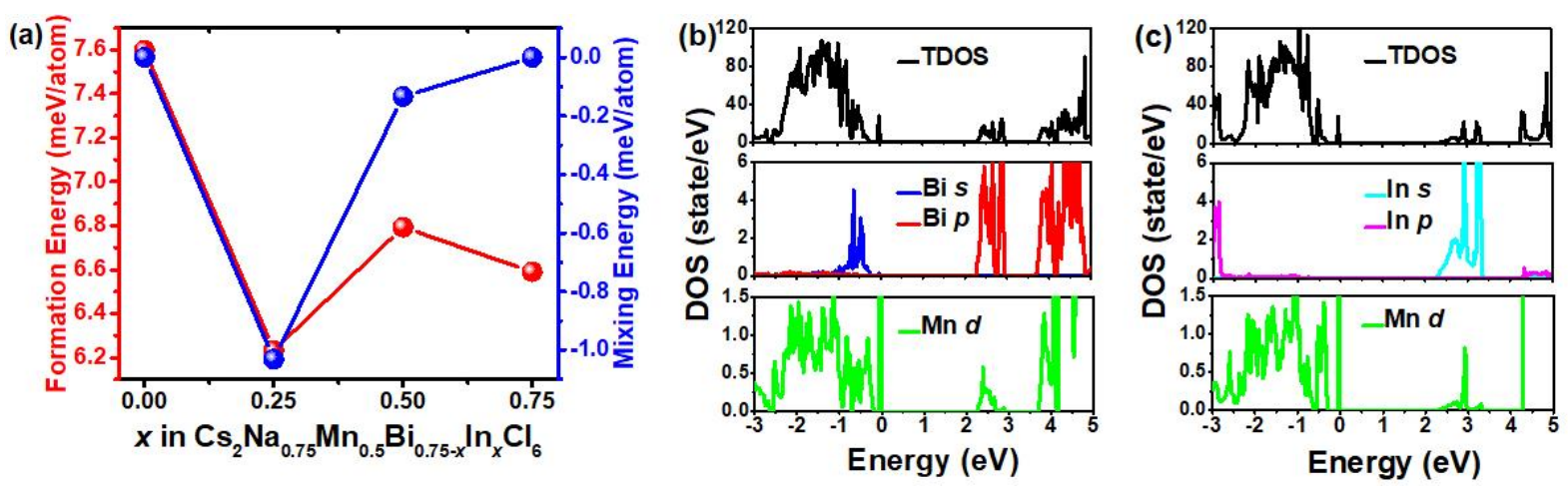

Figure 5. a) Calculated formation (mixing) energies per atom of $\mathrm{Cs}_{2} \mathrm{Na}_{0.75} \mathrm{Mn}_{0.5} \mathrm{Bi}_{0.75-x} \mathrm{In}_{x} \mathrm{Cl}_{6}$ as a function of $x$, with respect to $\mathrm{CsMnCl}_{3}, \mathrm{Cs}_{2} \mathrm{NaBiCl}_{6}$ and $\mathrm{Cs}_{2} \mathrm{NaInCl}_{6}$ $\left(\mathrm{Cs}_{2} \mathrm{Na}_{0.75} \mathrm{Mn}_{0.5} \mathrm{Bi}_{0.75} \mathrm{Cl}_{6}\right.$ and $\left.\mathrm{Cs}_{2} \mathrm{Na}_{0.75} \mathrm{Mn}_{0.5} \mathrm{In}_{0.75} \mathrm{Cl}_{6}\right)$. Electronic Density of States (DOS) for $\mathrm{Cs}_{2} \mathrm{Na}_{0.75} \mathrm{Mn}_{0.5} \mathrm{Bi}_{0.75} \mathrm{Cl}_{6}$ b) and $\mathrm{Cs}_{2} \mathrm{Na}_{0.75} \mathrm{Mn}_{0.5} \mathrm{In}_{0.75} \mathrm{Cl}_{6} \mathrm{c}$ ). 


\section{WILEY-VCH}

\section{Table of Contents entry}

Using chemical substitution strategy, we have discovered the orange-yellow-emitting $\mathrm{Cs}_{2} \mathrm{NaBi}_{1-x} \mathrm{In}_{x} \mathrm{Cl}_{6}: \mathrm{Mn}^{2+}$ crystals with indirect-direct band gaps. The successful adjustment of band gap and $\mathrm{Mn}^{2+}$-doped photoluminescence in the $\mathrm{Cs}_{2} \mathrm{NaBi}_{1-x} \mathrm{In}_{x} \mathrm{Cl}_{6}$ crystals demonstrated here will expand the utility and understanding of the optoelectronic character within the lead-free halide double perovskite family.

Keyword: Halide double perovskite; Bang gap energineering; $\mathrm{Mn}^{2+}$ doping

Jun Zhou", Ximing Rong", Peng Zhang, Maxim S. Molokeev, Peijia Wei, Quanlin Liu, Xiuwen Zhang*, Zhiguo Xia*

Manipulation of $\mathrm{Bi}^{3+} / \mathrm{In}^{3+}$ transmutation and $\mathrm{Mn}^{2+}$-doping effect on the structure and optical properties of double perovskite $\mathrm{Cs}_{2} \mathrm{NaBi}_{1-x} \mathrm{In}_{x} \mathrm{Cl}_{6}$

TOC

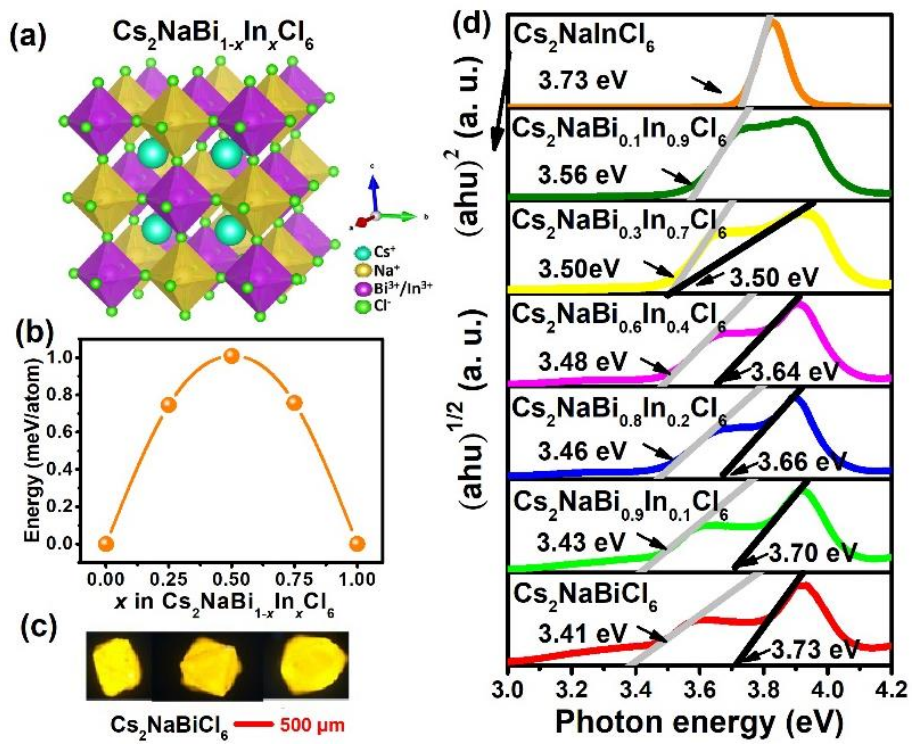




\section{WILEY-VCH}

\section{Supporting Information}

Manipulation of $\mathrm{Bi}^{3+} / \mathrm{In}^{3+}$ transmutation and $\mathrm{Mn}^{2+}$-doping effect on the structure and optical properties of double perovskite $\mathrm{Cs}_{2} \mathrm{NaBi}_{1-x} \mathrm{In}_{x} \mathrm{Cl}_{6}$

Jun Zhou", Ximing Rong", Peng Zhang, Maxim S. Molokeev, Peijia Wei, Quanlin Liu, Xiuwen Zhang*, Zhiguo Xia*
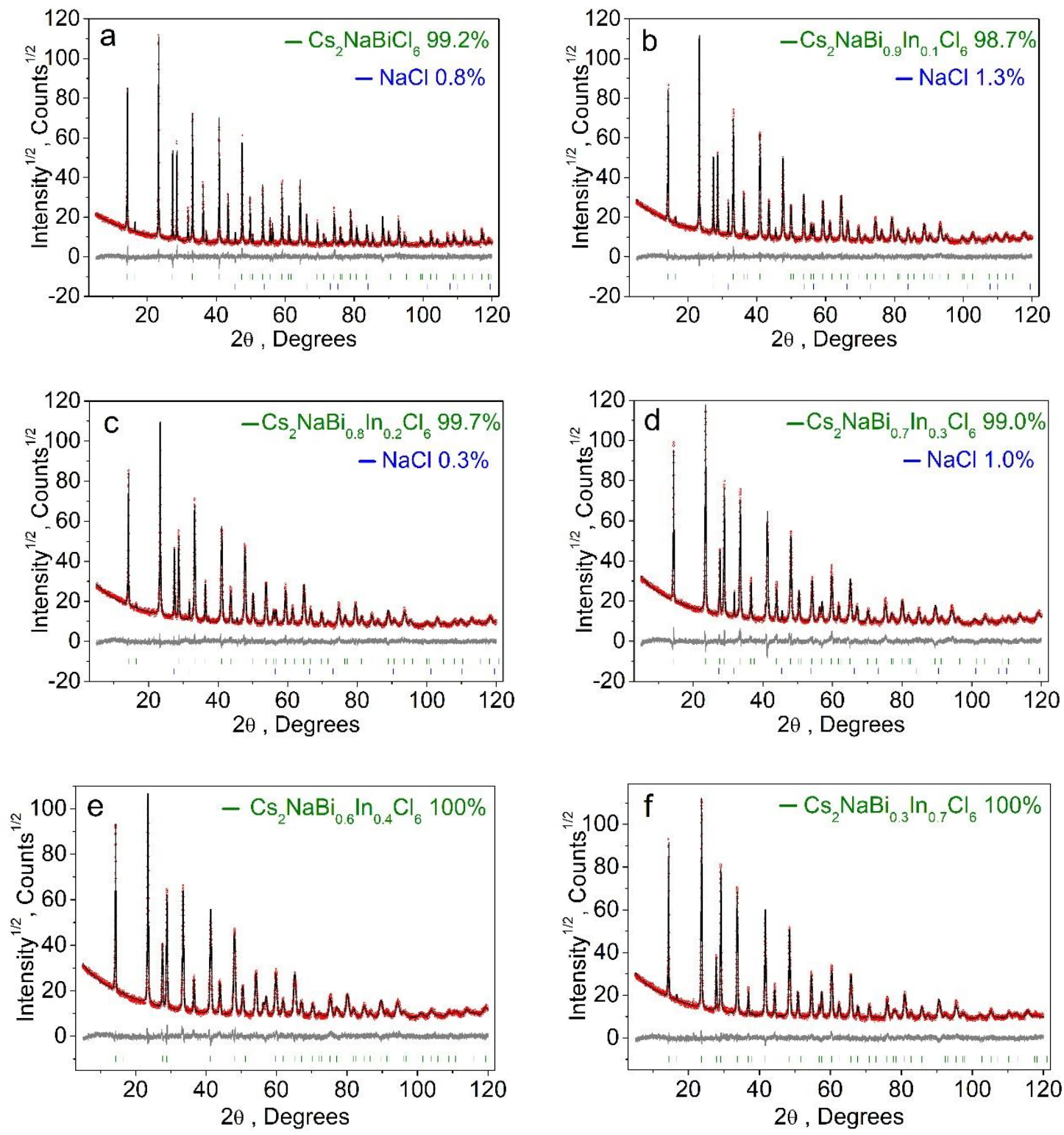


\section{WILEY-VCH}
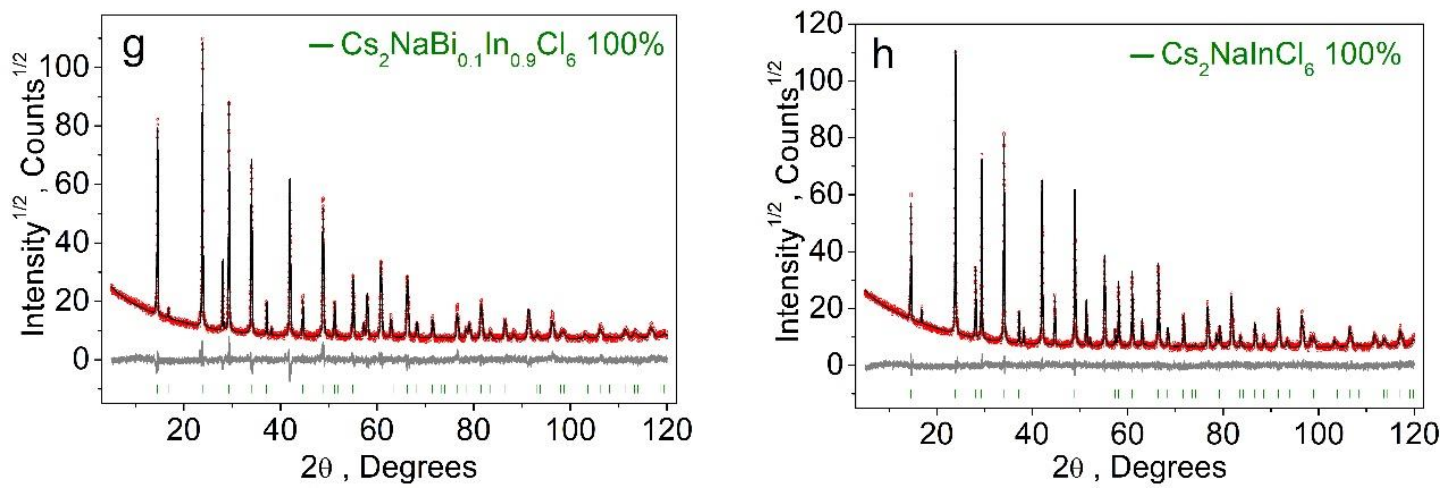

Figure S1. Difference Rietveld plot of $\mathrm{Cs}_{2} \mathrm{NaBi}_{1-x} \mathrm{In}_{x} \mathrm{Cl}_{6}: x=0$ a), $x=0.1 \mathrm{~b}$ ), $\left.x=0.2 \mathrm{c}\right), x=$ $0.3 \mathrm{~d}), x=0.4 \mathrm{e}), x=0.7 \mathrm{f}$ ), $x=0.9 \mathrm{~g}), x=1 \mathrm{~h}$ ).
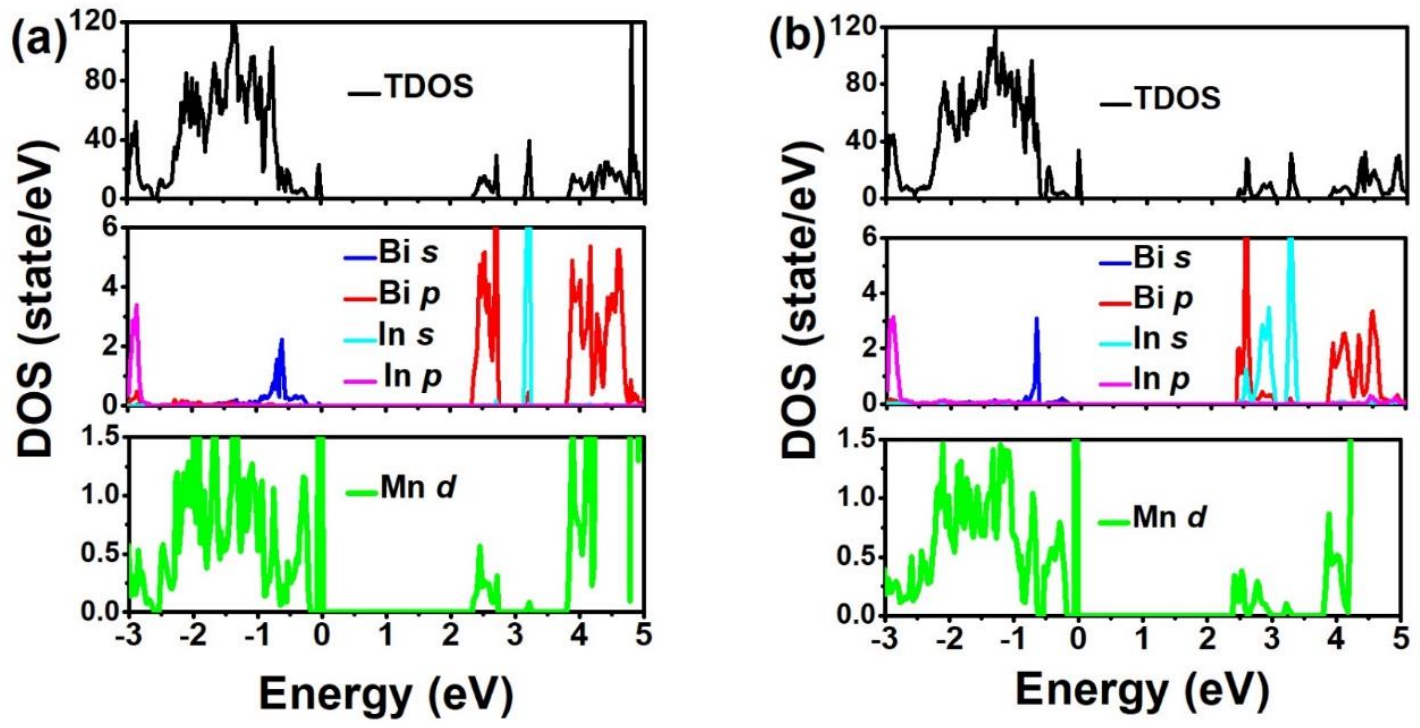

Figure S2. Electronic Density of States (DOS) for $\mathrm{Cs}_{2} \mathrm{Na}_{0.75} \mathrm{Mn}_{0.5} \mathrm{Bi}_{0.5} \mathrm{In}_{0.25} \mathrm{Cl}_{6}$ a) and $\left.\mathrm{Cs}_{2} \mathrm{Na}_{0.75} \mathrm{Bi}_{0.25} \mathrm{In}_{0.5} \mathrm{Cl}_{6} \mathrm{~b}\right)$.

Table S1. Main parameters of processing and refinement of the $\mathrm{Cs}_{2} \mathrm{NaBi}_{1-x} \mathrm{In}_{x} \mathrm{Cl}_{6}$ samples.

\begin{tabular}{|c|c|c|c|c|c|c|}
\hline$x$ & Phase & $\begin{array}{c}\text { Weight } \\
(\%)\end{array}$ & $\begin{array}{l}\text { Space } \\
\text { group }\end{array}$ & $\begin{array}{l}\text { Cell parameters }\left(^{\circ},\right. \\
\AA), \text { Cell volume }\left(\AA^{3}\right)\end{array}$ & $\begin{array}{l}R_{w p}, R_{p} \\
(\%), \chi^{2}\end{array}$ & $R_{B}(\%)$ \\
\hline \multirow{2}{*}{0} & $\mathrm{Cs}_{2} \mathrm{NaBiCl}_{6}$ & 99.2 & $F m-3 m$ & $\begin{array}{c}a=10.84230(6) \\
V=1274.57(2)\end{array}$ & \multirow{2}{*}{$\begin{array}{c}12.12 \\
9.43 \\
1.44\end{array}$} & 6.65 \\
\hline & $\mathrm{NaCl}$ & 0.8 & $F m-3 m$ & $\begin{array}{l}a=5.6396(3) \\
V=179.37(2)\end{array}$ & & 10.56 \\
\hline \multirow{2}{*}{0.1} & $\mathrm{Cs}_{2} \mathrm{NaBi}_{0.9} \mathrm{In}_{0.1} \mathrm{Cl}_{6}$ & 98.7 & $F m-3 m$ & $\begin{array}{l}a=10.8071(5) \\
V=1262.2(2)\end{array}$ & \multirow{2}{*}{$\begin{array}{c}8.54 \\
6.67 \\
1.29\end{array}$} & \multirow{2}{*}{$\begin{array}{l}2.94 \\
4.64\end{array}$} \\
\hline & $\mathrm{NaCl}$ & 1.3 & $F m-3 m$ & $\begin{array}{l}a=5.6414(3) \\
V=179.54(3)\end{array}$ & & \\
\hline \multirow[t]{2}{*}{0.2} & $\mathrm{Cs}_{2} \mathrm{NaBi}_{0.8} \mathrm{In}_{0.2} \mathrm{Cl}_{6}$ & 99.7 & $F m-3 m$ & $\begin{array}{l}a=10.7786(3) \\
V=1252.24(9)\end{array}$ & $\begin{array}{l}9.01 \\
6.94\end{array}$ & 2.89 \\
\hline & $\mathrm{NaCl}$ & 0.3 & $F m-3 m$ & $a=5.6391(5)$ & 1.38 & 4.40 \\
\hline
\end{tabular}


WILEY-VCH

\begin{tabular}{|c|c|c|c|c|c|c|}
\hline & & \multicolumn{5}{|c|}{$V=179.32(5)$} \\
\hline \multirow{2}{*}{0.3} & $\mathrm{Cs}_{2} \mathrm{NaBi}_{0.7} \mathrm{In}_{0.3} \mathrm{Cl}_{6}$ & 99.0 & $F m-3 m$ & $\begin{array}{c}a=10.7273(4) \\
V=1234.4(1)\end{array}$ & 10.83 & 5.72 \\
\hline & $\mathrm{NaCl}$ & 1.0 & $F m-3 m$ & $\begin{array}{l}a=5.6406(4) \\
V=179.47(4)\end{array}$ & $\begin{array}{c}5.78 \\
1.87\end{array}$ & 2.62 \\
\hline 0.4 & $\mathrm{Cs}_{2} \mathrm{NaBi}_{0.6} \mathrm{In}_{0.4} \mathrm{Cl}_{6}$ & 100 & $F m-3 m$ & $\begin{array}{c}a=10.7113(4) \\
V=1228.9\end{array}$ & $\begin{array}{l}9.05 \\
7.04 \\
1.51\end{array}$ & 3.82 \\
\hline 0.7 & $\mathrm{Cs}_{2} \mathrm{NaBi}_{0.3} \mathrm{In}_{0.7} \mathrm{Cl}_{6}$ & 100 & $F m-3 m$ & $\begin{array}{l}a=10.6199 \\
V=1197.74\end{array}$ & $\begin{array}{c}8.21 \\
6.28 \\
1.35\end{array}$ & 3.06 \\
\hline 0.9 & $\mathrm{Cs}_{2} \mathrm{NaBi}_{0.1} \mathrm{In}_{0.9} \mathrm{Cl}_{6}$ & 100 & $F m-3 m$ & $\begin{array}{l}a=10.5533 \\
V=1175.35\end{array}$ & $\begin{array}{c}12.65 \\
9.64 \\
1.69\end{array}$ & 7.63 \\
\hline 1 & $\mathrm{Cs}_{2} \mathrm{NaInCl}_{6}$ & 100 & $F m-3 m$ & $\begin{array}{c}a=10.53411(9) \\
V=1168.94\end{array}$ & $\begin{array}{l}9.60 \\
7.71 \\
1.25\end{array}$ & 2.01 \\
\hline
\end{tabular}

Table S2. Fractional atomic coordinates and isotropic displacement parameters $\left(\AA^{2}\right)$ of $\mathrm{Cs}_{2} \mathrm{NaBi}_{1-x} \mathrm{In}_{x} \mathrm{Cl}_{6}$.

\begin{tabular}{|c|c|c|c|c|c|}
\hline & $x$ & $y$ & $z$ & $B_{\text {iso }}$ & Occ. \\
\hline \multicolumn{6}{|c|}{$x=0$} \\
\hline $\mathrm{Bi}$ & 0 & 0 & 0 & $1.65(5)$ & 1 \\
\hline $\mathrm{Na}$ & 0.5 & 0.5 & 0.5 & $2.2(2)$ & 1 \\
\hline Cs & 0.25 & 0.25 & 0.25 & $3.51(6)$ & 1 \\
\hline $\mathrm{Cl}$ & 0.2460 & 0 & 0 & $2.71(7)$ & 1 \\
\hline \multicolumn{6}{|c|}{$x=0.1$} \\
\hline $\mathrm{Bi}$ & 0 & 0 & 0 & $1.38(4)$ & $0.843(8)$ \\
\hline In & 0 & 0 & 0 & $1.38(4)$ & $0.157(8)$ \\
\hline $\mathrm{Na}$ & 0.5 & 0.5 & 0.5 & $2.8(2)$ & 1 \\
\hline $\mathrm{Cs}$ & 0.25 & 0.25 & 0.25 & $3.29(6)$ & 1 \\
\hline $\mathrm{Cl}$ & $0.2440(3)$ & 0 & 0 & $3.27(7)$ & 1 \\
\hline \multicolumn{6}{|c|}{$x=0.2$} \\
\hline $\mathrm{Bi}$ & 0 & 0 & 0 & $1.02(5)$ & $0.640(8)$ \\
\hline In & 0 & 0 & 0 & $1.02(5)$ & $0.359(8)$ \\
\hline $\mathrm{Na}$ & 0.5 & 0.5 & 0.5 & $2.4(2)$ & 1 \\
\hline
\end{tabular}


WILEY-VCH

\begin{tabular}{|c|c|c|c|c|c|}
\hline Cs & 0.25 & 0.25 & 0.25 & $3.56(7)$ & 1 \\
\hline $\mathrm{Cl}$ & $0.2438(3)$ & 0 & 0 & 3.09 (8) & 1 \\
\hline \multicolumn{6}{|c|}{$x=0.3$} \\
\hline $\mathrm{Bi}$ & 0 & 0 & 0 & $0.53(6)$ & $0.36(1)$ \\
\hline In & 0 & 0 & 0 & $0.53(6)$ & $0.64(1)$ \\
\hline $\mathrm{Na}$ & 0.5 & 0.5 & 0.5 & $3.6(3)$ & 1 \\
\hline Cs & 0.25 & 0.25 & 0.25 & $3.48(8)$ & 1 \\
\hline $\mathrm{Cl}$ & 0.2439 & 0 & 0 & $2.51(9)$ & 1 \\
\hline \multicolumn{6}{|c|}{$x=0.4$} \\
\hline $\mathrm{Bi}$ & 0 & 0 & 0 & 0.87 (6) & $0.403(9)$ \\
\hline In & 0 & 0 & 0 & $0.87(6)$ & $0.597(9)$ \\
\hline $\mathrm{Na}$ & 0.5 & 0.5 & 0.5 & $2.3(2)$ & 1 \\
\hline $\mathrm{Cs}$ & 0.25 & 0.25 & 0.25 & $3.37(7)$ & 1 \\
\hline $\mathrm{Cl}$ & $0.2412(3)$ & 0 & 0 & $2.67(8)$ & 1 \\
\hline \multicolumn{6}{|c|}{$x=0.7$} \\
\hline $\mathrm{Bi}$ & 0 & 0 & 0 & $0.74(5)$ & $0.132(7)$ \\
\hline In & 0 & 0 & 0 & $0.74(5)$ & $0.868(7)$ \\
\hline $\mathrm{Na}$ & 0.5 & 0.5 & 0.5 & $1.30(19)$ & 1 \\
\hline Cs & 0.25 & 0.25 & 0.25 & $3.22(6)$ & 1 \\
\hline $\mathrm{Cl}$ & 0.2389 & 0 & 0 & $2.03(7)$ & 1 \\
\hline \multicolumn{6}{|c|}{$x=0.9$} \\
\hline $\mathrm{Bi}$ & 0 & 0 & 0 & $1.24(8)$ & $0.050(9)$ \\
\hline In & 0 & 0 & 0 & $1.24(8)$ & $0.950(9)$ \\
\hline $\mathrm{Na}$ & 0.5 & 0.5 & 0.5 & $0.7(2)$ & 1 \\
\hline Cs & 0.25 & 0.25 & 0.25 & 3.07 (9) & 1 \\
\hline $\mathrm{Cl}$ & 0.2390 & 0 & 0 & $1.74(9)$ & 1 \\
\hline \multicolumn{6}{|c|}{$x=1$} \\
\hline In & 0 & 0 & 0 & $1.03(4)$ & 1 \\
\hline $\mathrm{Na}$ & 0.5 & 0.5 & 0.5 & $2.1(2)$ & 1 \\
\hline $\mathrm{Cs}$ & 0.25 & 0.25 & 0.25 & $2.22(4)$ & 1 \\
\hline $\mathrm{Cl}$ & $0.2378(2)$ & 0 & 0 & $2.22(6)$ & 1 \\
\hline
\end{tabular}

Table S3. Observed main bond lengths $(\AA)$ of $\mathrm{Cs}_{2} \mathrm{NaBi}_{1-x} \mathrm{In}_{x} \mathrm{Cl}_{6}$. 
WILEY-VCH

\begin{tabular}{|c|c|c|c|}
\hline \multicolumn{4}{|c|}{$x=0$} \\
\hline $\mathrm{Bi}-\mathrm{Cl}$ & $2.667(4)$ & $\mathrm{Na}-\mathrm{Cl}^{\mathrm{i}}$ & $2.754(4)$ \\
\hline \multicolumn{4}{|c|}{$x=0.1$} \\
\hline$(\mathrm{Bi} / \mathrm{In})-\mathrm{Cl}$ & $2.637(3)$ & $\mathrm{Na}-\mathrm{Cl}^{\mathrm{i}}$ & $2.767(3)$ \\
\hline \multicolumn{4}{|c|}{$x=0.2$} \\
\hline$(\mathrm{Bi} / \mathrm{In})-\mathrm{Cl}$ & $2.628(3)$ & $\mathrm{Na}-\mathrm{Cl}^{\mathrm{i}}$ & $2.761(3)$ \\
\hline \multicolumn{4}{|c|}{$x=0.3$} \\
\hline$(\mathrm{Bi} / \mathrm{In})-\mathrm{Cl}$ & $2.616(4)$ & $\mathrm{Na}-\mathrm{Cl}^{\mathrm{i}}$ & $2.748(4)$ \\
\hline \multicolumn{4}{|c|}{$x=0.4$} \\
\hline$(\mathrm{Bi} / \mathrm{In})-\mathrm{Cl}$ & $2.584(4)$ & $\mathrm{Na}-\mathrm{Cl}^{\mathrm{i}}$ & $2.772(4)$ \\
\hline \multicolumn{4}{|c|}{$x=0.7$} \\
\hline$(\mathrm{Bi} / \mathrm{In})-\mathrm{Cl}$ & $2.537(3)$ & $\mathrm{Na}-\mathrm{Cl}^{\mathrm{i}}$ & $2.773(3)$ \\
\hline \multicolumn{4}{|c|}{$x=0.9$} \\
\hline$(\mathrm{Bi} / \mathrm{In})-\mathrm{Cl}$ & $2.522(4)$ & $\mathrm{Na}-\mathrm{Cl}^{\mathrm{i}}$ & $2.755(4)$ \\
\hline \multicolumn{4}{|c|}{$x=1$} \\
\hline $\mathrm{In}-\mathrm{Cl}$ & $2.505(3)$ & $\mathrm{Na}-\mathrm{Cl}^{\mathrm{i}}$ & $2.763(3)$ \\
\hline
\end{tabular}

Symmetry code: (i) $x, y+1 / 2, z+1 / 2$.

Table S4. Calculated main bond lengths $(\AA)$ of $\mathrm{Cs}_{2} \mathrm{NaBi}_{1-x} \mathrm{In}_{x} \mathrm{Cl}_{6}$.

\begin{tabular}{ccccc}
\hline \multicolumn{5}{c}{$x=0$} \\
\hline $\mathrm{Bi}-\mathrm{Cl}$ & $2.725(7)$ & $(\mathrm{Bi} / \mathrm{In})-\mathrm{Cl} 2.725(7)$ & $\mathrm{In}-\mathrm{Cl}$ \\
\hline \multicolumn{5}{c}{$x=0.25$} \\
\hline $\mathrm{Bi}-\mathrm{Cl}$ & $2.721(2)$ & $(\mathrm{Bi} / \mathrm{In})-\mathrm{Cl} 2.682(4)$ & $\mathrm{In}-\mathrm{Cl}$ & $2.566(1)$ \\
\hline \multicolumn{5}{c}{$x=0.5$} \\
\hline $\mathrm{Bi}-\mathrm{Cl}$ & $2.716(7)$ & $(\mathrm{Bi} / \mathrm{In})-\mathrm{Cl} 2.639(6)$ & $\mathrm{In}-\mathrm{Cl}$ & $2.562(5)$ \\
\hline \multicolumn{5}{c}{$x=0.75$} \\
\hline $\mathrm{Bi}-\mathrm{Cl}$ & $2.711(5)$ & $(\mathrm{Bi} / \mathrm{In})-\mathrm{Cl} 2.597(5)$ & $\mathrm{In}-\mathrm{Cl}$ & $2.559(5)$ \\
\hline $\mathrm{Bi}-\mathrm{Cl}$ & & $x=1$ & & \\
\hline
\end{tabular}

